Pacific Northwest National Laboratory

Operated by Battelle for the

U.S. Department of Energy

\title{
Comparison of Blade-Strike Modeling Results with Empirical Data
}

\section{Gene R. Ploskey \\ Thomas J. Carlson \\ Pacific Nothwest National Laboratory}

March 2004

Wind and Hydropower Technologies 


\title{
DISCLAIMER
}

This report was prepared as an account of work sponsored by an agency of the United States Government. Neither the United States Government nor any agency thereof, nor Battelle Memorial Institute, nor any of their employees, makes any warranty, express or implied, or assumes any legal liability or responsibility for the accuracy, completeness, or usefulness of any information, apparatus, product, or process disclosed, or represents that its use would not infringe privately owned rights. Reference herein to any specific commercial product, process, or service by trade name, trademark, manufacturer, or otherwise does not necessarily constitute or imply its endorsement, recommendation, or favoring by the United States Government or any agency thereof, or Battelle Memorial Institute. The views and opinions of authors expressed herein do not necessarily state or reflect those of the United States Government or any agency thereof.

\author{
PACIFIC NORTHWEST NATIONAL LABORATORY \\ operated by \\ BATTELLE \\ for the \\ UNITED STATES DEPARTMENT OF ENERGY \\ under Contract DE-AC06-76RL01830
}

This document was printed on recycled paper. 


\title{
Comparison of Blade-Strike Modeling Results with Empirical Data
}

\author{
G. R. Ploskey \\ T. J. Carlson
}

March 2004

Prepared for

the U.S. Department of Energy

under Contract DE-AC06-76RL01830

Pacific Northwest National Laboratory

Richland, Washington 99352 


\section{Summary}

Fish passing through hydroturbines are subjected to a variety of conditions that can injure or kill them. Hydropower owners and operators need to understand injury mechanisms to identify designs and operational criteria to increase the survival of fish passing through dams. Of the various mechanisms believed to be responsible for injuries to fish during turbine passage, strike by turbine runner blades is one of the most predominant.

This study is the initial stage of further investigation into the dynamics of injury to fish during passage through a turbine runner. As part of the study, Pacific Northwest National Laboratory (PNNL) estimated the probability of blade strike, and associated injury, as a function of fish length and turbine operating geometry at two adjacent turbines in Powerhouse 1 of Bonneville Dam. Units 5 and 6 had identical intakes, stay vanes, wicket gates, and draft tubes, but Unit 6 had a new runner and curved discharge ring to minimize gaps between the runner hub and blades and between the blade tips and discharge ring. We used a mathematical model to predict blade strike associated with two Kaplan turbines and compared results with empirical data from biological tests conducted in 1999 and 2000. Blade-strike models take into consideration the geometry of the turbine blades and discharges as well as fish length, orientation, and distribution along the runner.

Previously, we integrated historical and recent test results for turbine passage in conjunction with published theory for turbine runner blade strike to examine the relationship among fish size, turbine operation, and injury to fish during turbine passage. Use of Monte Carlo techniques allowed consideration of factors such as fish orientation at entry to the runner, distribution of fish along runner blades, and important sources of error and variability into the strike probability estimation. Blade strike was considered for analysis because it is an obvious source of injury, and injury mechanisms have been mathematically and empirically studied.

The first phase of this study included a sensitivity analysis to consider the effects of difference in geometry and operations between families of turbines on the strike probability response surface. The analysis revealed that the orientation of fish relative to the leading edge of a runner blade and the location that fish pass along the blade between the hub and blade tip are critical uncertainties in blade-strike models.

Blade-strike models predicted that injury increases with decreasing discharge and with increasing fish-passage radius. Over a range of discharges, the average prediction of injury from blade strike was two to five times higher than average empirical estimates of visible injury from shear and mechanical devices. However, differences in relative blade velocities may explain why predictions of injury were within $2-3 \%$ of empirical 48 -h mortality estimates for fish passing at mid-blade and tip locations but were 6-8\% higher than 48-h mortality estimates for fish passing near the hub. Mortal injuries are more likely to result when relative blade velocities are high like those at mid-blade and tip locations. Empirical estimates of mortality may be better metrics for comparison to predicted injury rates than other injury measures for fish passing at mid-blade and blade-tip locations. 
For future studies, we intend to extend the blade-strike model by including more realistic treatment of the physics of encounters between fish and turbine blades. We also intend to model Francis as well as Kaplan turbines. It should be possible to estimate the probability of strike and features of impact dynamics on encounter based on physical arguments alone. This approach will reduce reliance on model coefficients that must be empirically estimated and focus on biological factors influencing whether a fish is injured or killed when struck. Better understanding of aspects of blade strike and impact dynamics will lead to injury mechanics hypotheses that can be tested under laboratory conditions using accepted biomechanics study methods. 


\section{Acknowledgments}

Many people have contributed to the success of this project. Within Pacific Northwest National Laboratory (PNNL), we much appreciate Dennis Dauble's involvement and oversight. Wilbur Moyer with the U.S. Army Corps of Engineers (USACE) Portland District at Bonneville Dam provided many design drawings and helped us interpret some of the older drawings. Rod Wittinger and Thomas Freeman with the Hydraulic Design Center (HDC), Portland District, also provided drawings, hard-to-obtain dimensions and turbine statistics, and recommendations. Lee Sheldon, a hydraulic design expert and contractor to HDC made valuable recommendations on hydraulic calculations. Finally, we thank the U.S Department of Energy Hydropower Program, which funded this study. 


\section{Contents}

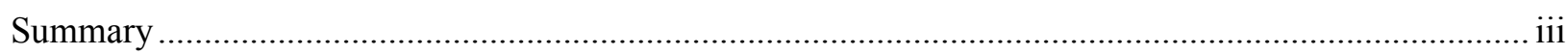

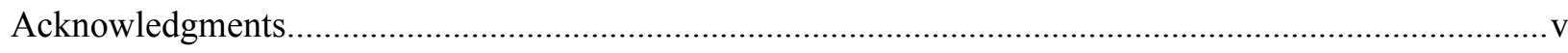

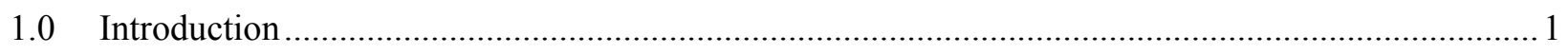

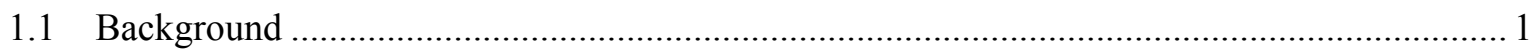

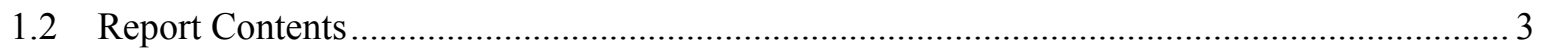

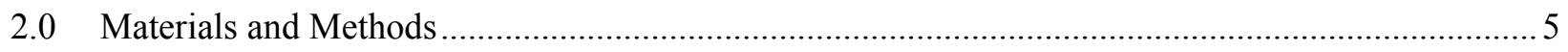

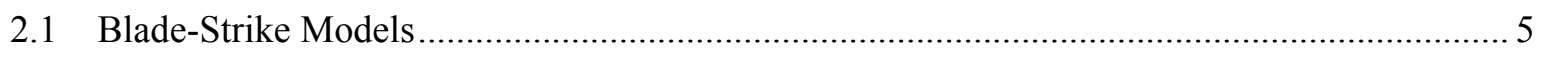

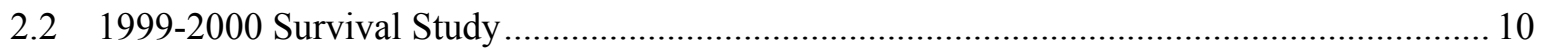

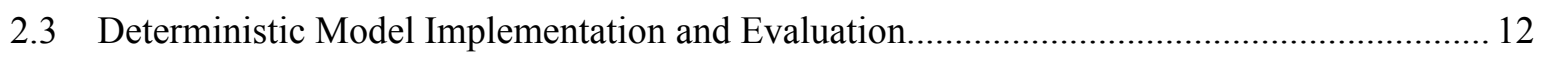

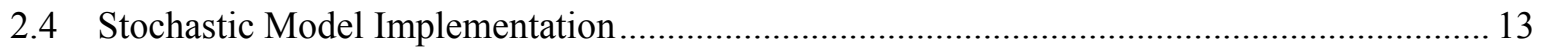

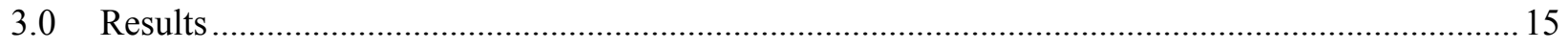

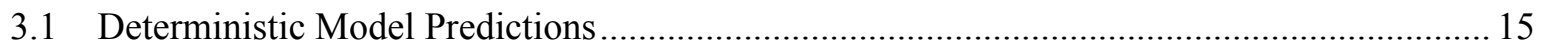

3.2 Model Predictions Versus Empirical Results .............................................................. 16

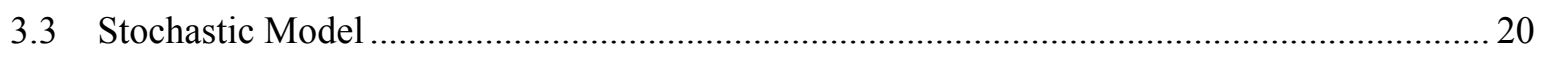

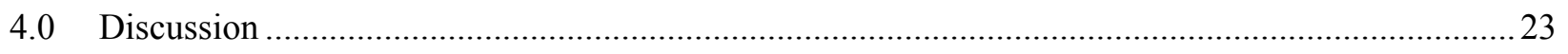

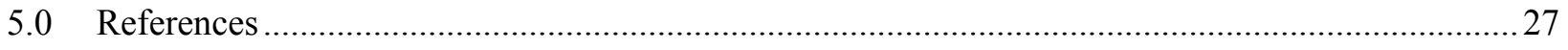




\section{Figures}

1 Cross Section of a Typical Columbia River Federal Hydropower System Kaplan Turbine

2 Plan View Showing Radial Dimensions of the Hub and Throat of an Existing Kaplan

Turbine at Unit 5 and a New Minimum Gap Runner Turbine at Unit 6 at Bonneville Dam

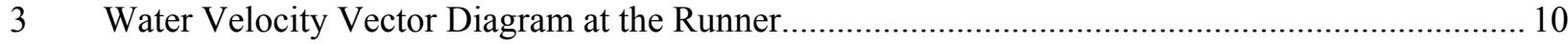

4 Regression of the Probability of Blade-Strike Injury on the Probability of Blade Strike................. 15

5 Response Surface of the Probability of Injury ( $\mathrm{P}$ _ injury) from Blade Strike Relative to Discharge and Fish-Passage Radius at an Existing Kaplan and a New Minimum-Gap-Runner

Kaplan

6 Plot of Predictions of Blade Strike as a Function of Discharge for Unit 5 and Unit 6

7 Among-Unit Differences in Probabilities of Blade Strike Displayed as a Function of Mean

Discharge

8 Bar Chart Comparing Probabilities of Predicted Blade-Strike Injury ( $\mathrm{P}$ _injury) with Empirical Estimates of Shear + Mechanical Injury, Visible Injury, 1-h Mortality, 48-h

Mortality, Dead or Injured, or Dead, Injured, or Loss of Equilibrium for Unit 5 and Unit 6 .

9 Plots of Various Normal Input Distributions of Relative Fish Length and Standardized Regression Coefficients that Indicate the Sensitivity of Injury Predictions to Fish Length, Turbine Discharge, and Fish-Passage Radius

10 Plots of Various Uniform Input Distributions of Relative Fish Length and Standardized Regression Coefficients that Indicate the Sensitivity of Injury Predictions to Fish Length, Discharge, and Fish-Passage Radius

11 Comparison of Empirical and Predicted Injury Probabilities for Fish Passing from the Mid-Blade to the Tip of Runner Blades. 


\section{Tables}

1 Standardized Variable Names, Definitions, and the Names Used in the Original Paper................... 5

2 Excel Spreadsheet Showing Calculations of Average Radii for Three Equal Areas Between the Hub and the Runner Tip for the Existing Kaplan Runner in Unit 5 ....................................... 9

3 Coefficients of Correlations of Blade Strike and Blade-Strike Injury with Flow-Related Independent Operational Variables from the 1999-2000 Study. ................................................. 16

4 Stepwise Regression Models for Predicting Empirical Estimates of Injury or Mortality from

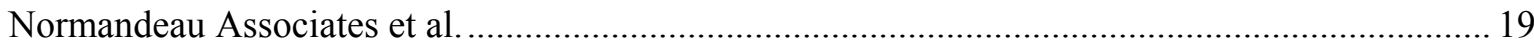




\subsection{Introduction}

The overall objective of this project is to develop a relationship between fish size, turbine operations, and risk of injury for salmonids passing through turbines. Information on blade strike is needed to develop biological tests for establishing biocriteria for operation of turbines. Optimized operations to minimize blade encounter provide the most promise for reducing injury and maximizing survival of juvenile salmonids.

To assist the U.S. Department of Energy Hydropower Program in gaining information on blade strike, Pacific Northwest National Laboratory (PNNL) researchers integrated historical and recent test results for turbine passage in conjunction with published theory for turbine runner blade strike to examine the relationship among fish size, turbine operation, and injury to fish during turbine passage. Use of Monte Carlo techniques allowed consideration of factors such as fish orientation at entry to the runner, distribution of fish along runner blades, and important sources of error and variability in strike probability estimation. Blade strike was considered for analysis because it is an obvious source of injury, and bladestrike injury mechanisms have been mathematically and empirically studied.

\subsection{Background}

Recent investigations of turbine passage survival strongly indicate that the majority of direct fish injury and mortality occurs in the immediate vicinity of the turbine runner. Injuries to fish appear to occur as a result of contact with turbine runner blades or exposure to the hydraulic conditions close to the blades or in the wake of the blades. In addition, most new turbine designs focus on improving the design of the turbine runner and discharge cone.

The turbine passage environment extends from the trash racks at the upstream end of the turbine intakes through the draft tube exit where the turbine discharge enters the powerhouse tailrace (Figure 1). The time of passage for fish through a typical turbine is seldom more than about a minute (Carlson and Duncan 2003). The exact passage time depends on the flow rate through the turbine as well as some features of turbine design. The portion of the turbine that probably is most dangerous for fish is the section between the stay vane-wicket gate cascade and the elbow in the turbine draft tube immediately downstream from the turbine runner. In this region, flow through the turbine initially undergoes high acceleration during passage through the wicket gates and turbine runner followed by deceleration and turbulence as the flow expands under the turbine runner. In particular, passage through the turbine runner is risky because of the potential for contact with the turbine runner blades.

Runner blade contact can take many forms (USACE 2004). One form of special interest is direct contact between a fish and the leading edge of a turbine blade. This type of contact is called "strike." Several researchers over the past several decades have investigated strike. Their work has taken two forms: (1) derivation of numerical models to estimate the probability of strike and (2) field studies to directly observe the rate of occurrence of blade strike and the types of injuries fish experience when struck by turbine blades. 


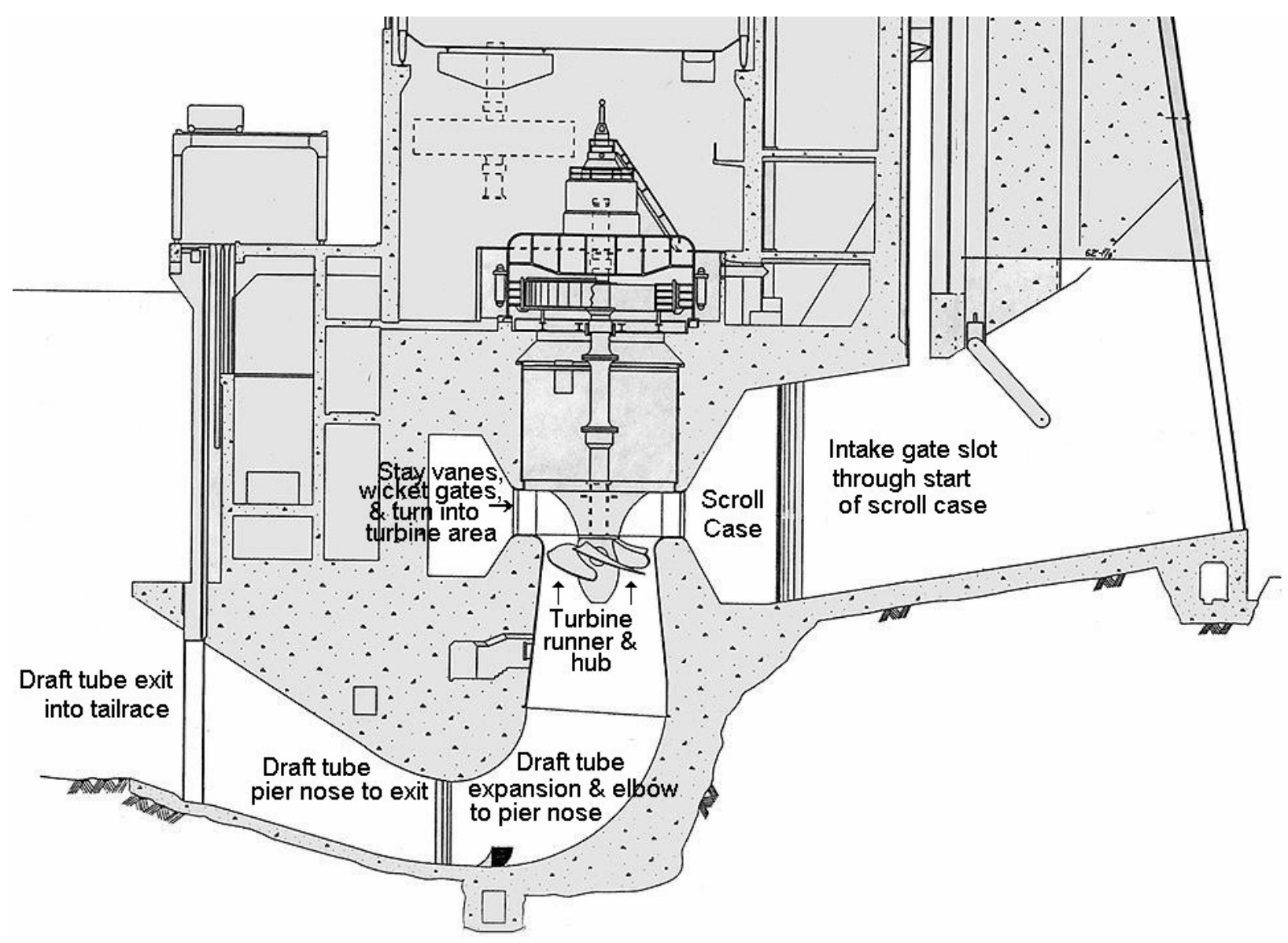

Figure 1. Cross Section of a Typical Columbia River Federal Hydropower System Kaplan Turbine

The variables affecting the probability of strike were identified by early researchers such as Von Raben (1957) who developed one of the first equations for predicting probability of strike. This work was expanded by Monten (1985) and Solomon (1988) who also conducted field studies to aid understanding of the injuries caused by strike and to better understand the dynamics of fish passage through turbine runners. These studies identified several physical and biological variables involved in prediction of strike and the injury and mortality rates resulting from strike. Important physical variables identified were the number and length of blades in a turbine runner, the rotational speed of the runner, gaps near the tips and hub of turbine runner blades, discharge through the runner, and the velocity of impact which is related to the relative velocity of the turbine runner blade to that of the fish. To complicate the matter further, relative impact velocity is a function of the location along the blade where impact occurs with impact velocity increasing as radial distance along runner blades increases from a runner blade's hub to its tip.

Important biological variables identified by researchers include fish length, mass, stiffness, and others related to the ease of tissue trauma, which is species and age specific. Also identified as important is the distribution of fish as they pass through the turbine wicket gates and behavior that might influence the aspect a fish presents to an approaching runner blade. For Kaplan turbines, fish that pass higher through the wicket gate openings will pass nearer the runner hub, while those passing lower through the wicket 
gate openings will pass nearer to the tips of the runner blades. Field studies have shown that the risk of injury and death is significantly higher for fish that pass through the turbine runner near blade tips than those that pass nearer the runner hub (Normandeau Associates et al. 2000). Reviews that present the evolution in understanding of dynamics of blade strike have been published by Bell (1981, 1991), Eicher et al. (1987), Stone and Webster Environmental Services (1992), Čada et al. (1997), Coutant and Whitney (2000), and Pavlov et al. (2002).

Blade-strike probabilities have been estimated by Tikhij and Viktorov (1940), Von Raben (1957), Monten (1985), Solomon (1988), Bell (1991), Turnpenny et al. (1992, 2000), Pavlov et al. (2002), and the U.S. Army Corps of Engineers, Portland District (1995, 2000). Using the equation of Bell (1991) and a strike injury adjustment of Turnpenny (1998), Amaral et al. (2003) found that predictions were within about $4 \%$ of immediate survival estimates for a prototype turbine. In all cases, researchers have found estimated probabilities of blade strike exceed observed injury and mortality rates. These differences appear to be a function of biological factors and the physical dynamics of the blade-fish impact process (Turnpenny et al. 2000). The end result is that more accurate estimates of blade strike and its consequences require derivation of parameters that adjust initial estimates of the probability of fish encounters with turbine blades for biologically conditioned probabilities of strike and then injury resulting from strike. The difference between blade strike and blade encounter is explained by the findings of Turnpenny et al. (2000) where alignment of a fish's center of mass as well as the fish's mass were found to be important in whether a fish's encounter with a runner blade leading edge would result in strike or near miss.

As the study of strike by runner blades progresses, it is clear that semantic challenges will develop. This results from initial misuse of the term "strike" where strike means contact between a runner blade and a fish. The first investigators have used "strike" when another term, such as "encounter" would have been better. The laboratory work of Turnpenny et al. (2000) has shown that fish geometrically aligned so that strike would occur if other factors didn't intercede would have a variable probability of collision with a blade depending upon their absolute mass, the location of the center of mass relative to the leading edge of the turbine blade, and the fluid dynamics at the leading edge of the turbine blade. Factors other than these most likely also contribute to the collision probability. Furthermore, it is becoming clear that a number of factors influence whether a fish is injured or killed during a collision with a turbine blade. It is also possible that conditions near turbine blades may present risk of injury in addition to the risk of strike.

This report retains the historical use of "strike" while challenging its use in future discussion of the process of strike and injury of fish upon encounter with turbine runner blades.

\subsection{Report Contents}

In this report, we estimated the probability of blade strike and associated injury as a function of fish length and turbine operating geometry at two adjacent turbines at Powerhouse 1 of Bonneville Dam and compared the predictions with empirical results obtained in a field study by Normandeau Associates et al. (2000). The intakes, stay vanes, wicket gates, and draft tubes of Units 5 and 6 were identical. However, Unit 6 had a new "minimum gap runner" (MGR) that minimized gaps between the runner hub and blades, and a new curved discharge ring was installed to minimize gaps between the blade tips and discharge ring at all blade angles. Section 2.0 of this report describes the four blade-strike models we reviewed, analysis 
of the 1999-2000 survival study data, implementation and evaluation of a deterministic model, and implementation of a stochastic model. Section 3.0 provides results, which are discussed in Section 4.0. 


\subsection{Materials and Methods}

In the following sections, we review blade-strike models and describe calculations required to derive inputs for Kaplan turbine Units 5 and 6 at Bonneville Dam, as configured in 1999 and 2000. Second, we describe the extensive fish survival study conducted at those units in 1999 and 2000, and the operational data available as input for blade-strike models. Third, we describe implementation of a deterministic blade-strike model and how predictions were compared to empirical operations, injury, and survival data. Fourth, we describe the implementation a stochastic version of the Turnpenny et al. (2000) model and how it was used to investigate uncertainties in the modeling process.

\subsection{Blade-Strike Models}

We reviewed four papers describing deterministic blade-strike models (Von Raben 1957; Bell 1991; Turnpenny 2000; and Pavlov et al. 2002) and found that they were all essentially the same, except for the semantics of naming variables and describing equations. We standardized variable names so that models could be compared easily. Standardized variables are defined and referenced to names in original papers in Table 1.

The Von Raben's (1957) model had the form

$$
P=\frac{l \cdot n \cdot N \cdot \cdot_{T H} \cdot \cos \theta}{Q}
$$

where all variables are defined in Table 1 and $\cos =\operatorname{cosine}$.

Table 1. Standardized Variable Names, Definitions, and the Names Used in the Original Paper

\begin{tabular}{|c|c|c|c|c|c|}
\hline $\begin{array}{c}\text { Standardized } \\
\text { Variable Name } \\
\end{array}$ & Definition & $\begin{array}{c}\text { Von Raben } \\
(1957) \\
\end{array}$ & Bell (1991) & $\begin{array}{c}\text { Turnpenny et al. } \\
(2000) \\
\end{array}$ & $\begin{array}{c}\text { Pavlov et al. } \\
(2002)\end{array}$ \\
\hline$P$ & Probability of blade strike & $P$ & $P$ & $P$ & $P$ \\
\hline$l$ & Fish length, $\mathrm{ft}$ & $l$ & $l$ & $l$ & $l$ \\
\hline$n$ & Number of runner blades & $n$ & $n$ & No. of Blades & $N$ \\
\hline$N$ & $\begin{array}{l}\text { Runner rotation rate, revolutions } \\
\text { /min }\end{array}$ & $R^{1}$ & $N$ & RPM of runner & $n^{1}$ \\
\hline$A_{\text {Tip }}$ & $\begin{array}{l}\text { Area swept by the runner: } \\
\pi \cdot\left(\mathrm{R}_{\mathrm{Tip}}^{2}-\mathrm{R}_{\mathrm{Hub}}{ }^{2}\right)^{2}, \mathrm{ft}^{2}\end{array}$ & $\mathrm{a}$ & $=\pi \cdot\left(\mathrm{r}_{0}{ }^{1}-\mathrm{r}_{1}{ }^{2}\right)$ & $\begin{array}{l}\text { Runner swept } \\
\text { area }\end{array}$ & $=\pi \cdot\left(\mathrm{R}^{2}-\mathrm{r}^{2}\right)$ \\
\hline$\theta$ & $\begin{array}{l}\text { Angle between axial water velocity } \\
\text { vector and the absolute water } \\
\text { velocity vector }\end{array}$ & $\alpha$ & $\theta$ & $\mathrm{a}$ & $\alpha$ \\
\hline Q & Discharge, $\mathrm{ft}^{3} / \mathrm{s}$ & $\mathrm{f}$ & $\mathrm{Q}$ & Discharge & $\mathrm{Q}$ \\
\hline$V_{\text {axial }}$ & Axial velocity $(\mathrm{ft} / \mathrm{s}) ;=\mathrm{Q} / A_{T H}$ & $\frac{a}{f}=\frac{1}{V_{\text {axial }}}$ & $V_{\text {axial }}$ & $\frac{\text { Discharge }}{\text { Runner Swept Area }}$ & $V^{-1}$ \\
\hline
\end{tabular}


By substituting $1 / V_{\text {axial }}$ for the equivalent term $A_{T H} / Q$ (see $V_{\text {axial }}$ in Table 1) and rearranging the order of products we obtain:

$$
P=\frac{n \cdot N \cdot l \cdot \cos \theta}{V_{\text {axial }}}
$$

Equation 1.2 is the same equation described by Ronald Nece (Bell 1991):

$$
P=\frac{n \cdot N}{60} \cdot \frac{l \cdot \cos \theta}{V_{\text {axial }}}
$$

except for 60, which serves to convert runner revolutions/min $(N)$ to revolutions/s, which are the units for $N$ in Equations 1.1 and 1.2.

Pavlov et al. (2002) presented an equation for fish entering the inter-blade space at angle $\theta$ :

$$
P=l \cdot N \cdot n \cdot \cos (\theta) \cdot V_{\text {axial }}^{-1}
$$

Equation 1.4 predicts the same probabilities as Equations 1.1-1.3 and 1.5. Pavlov et al. (2002) stated that Hinterleitner (as cited in Tikhij and Victorov 1940) was the first to develop the equation to calculate potential collision of fish with runner blades in 1937, but the exact formulation of the equation was not presented.

Turnpenny et al. (2000) stated that calculations of runner strike probabilities were first reported by Von Raben (1957) and were subsequently used by many researchers. The principle is simple: for a fish to pass through the turbine on any given streamline without striking a runner blade, it must pass after the sweep of one blade and before the sweep of the next (Turnpenny et al. 2000). The probability of strike is related to the ratio of fish length to water length, where any fish longer than the length of a streamline cut by successive blades will be struck. The equation presented by Turnpenny et al. (2000) was:

$$
P=\frac{\text { Fish Length }}{\text { Water Length }}=\frac{1}{\left(\frac{V_{\text {axial }}}{\cos \theta \cdot n \cdot \frac{N}{60}}\right)}
$$

and it predicts the same probabilities as Equations 1.1-1.4.

Unlike other deterministic models, the Turnpenny et al. (2000) STRIKER model uses an empirically derived adjustment called a "mutilation ratio" to adjust strike probabilities calculated by Equation 1.5. Turnpenny (1998) found that blade collision is more likely for massive fish than small fish because larger fish have more momentum carrying them into the blade. Small fish with more surface area relative to mass were more likely to be dragged around the blade. Empirical data from Turnpenny et al. (1992) were used to develop a regression equation relating the mutilation ratio to fish length for salmonid smolts: 


$$
M R=0.15533 \operatorname{Ln}(l)+0.0125
$$

where $M R=$ mutilation ratio, $L n=$ natural logarithm, and $l=$ fish length $(\mathrm{cm})$. The term "mutilation ratio" was first described by Von Raben (1957), who observed that his predictions overestimated fish injury in Kaplan turbines by 43\%. In Section 3.0 of this report, we presented estimates of $P$ from Equation 1.5 and also multiplied $P$ by MR from Equation 1.6 to provide estimates of the probability of injury due to blade strike.

Except the angle $\theta$, most variables in Equation 1.5 are easily obtained, calculated, or estimated. For example, fish length can be based on mean lengths of released fish, as described in the Normandeau Associates et al. (2000) field study, from fyke-net catches in turbine entrances, or from length statistics of fish in smolt-monitoring facilities (SMF). The latter requires the perhaps dubious assumption that length statistics of guided fish in SMF are the same as those of unguided fish that pass through turbines. Axial velocity of water at the runner entrance is a straightforward calculation from turbine discharge and bladeswept area (Table 1). The number of runner blades and runner rotation speed (5 and 75 revolutions per minute $[\mathrm{RPM}]$ at the Bonneville units) can be obtained from drawings or performance reports.

An estimate of the angle $\theta$ in Equation 1.5 requires a series of calculations that begin at the wicket gate level and end at the level of the runner blades. The first step was to calculate

$$
V_{\text {axial_wg }}=Q / A_{w g c}
$$

where $V_{\text {axial_wg }}=$ axial velocity of water at the wicket gate $(\mathrm{ft} / \mathrm{s}), \mathrm{Q}=$ turbine discharge $\left(\mathrm{ft}^{3} / \mathrm{s}\right)$, and $A_{\text {wgc }}$ is the surface area $\left(\mathrm{ft}^{2}\right)$ of the side of a imaginary vertical cylinder, where the cylinder side touches the downstream tips of all wicket gates.

$$
A_{w g c}=2 \pi \cdot R_{w g c} \cdot h_{w g}
$$

where $R_{w g c}=$ the radius of the vertical imaginary cylinder and $h_{w g}=$ wicket gate height (ft). We calculated $R_{w g c}$ (which depends upon wicket gate angle) by a linear regression between two points, i.e., the radius when the wicket gates were closed and the radius when the wicket gates were fully open. The equation was

$$
R_{\text {wgc }}=-0.3238 * \mathrm{WGA}+168,
$$

where WGA $=$ wicket gate angle $\left(^{\circ}\right)$. This allowed us to calculate $R_{w g c}$ for every fish release treatment in the 1999-2000 survival study. For Units 5 and 6, we derived WGA by regressing closed and wide open wicket gate angles on extremes of percent servomotor stroke, which engineers had measured over the range of wicket-gate motion with a machinists scale. Unlike WGA, percent servomotor stroke was measured for every fish release treatment, but we needed wicket-gate angle to estimate water velocity vectors. We forced the intercept of the regression line through zero and obtained a slope of 0.837 , so 
WGA $=$ percent servomotor stroke $\times 0.837$ for those turbines and years. The maximum wicket gate angle $\left(85.24^{\circ}\right)$ was obtained from Drawing 2672-1270 from Voith Siemens HydroPower Generation, Inc., out of York, Pennsylvania.

The next step was to calculate the tangential velocity $(\mathrm{ft} / \mathrm{s})$ at the wicket gate $\left(\mathrm{V}_{\mathrm{t}_{\mathrm{w}} \mathrm{wg}}\right)$ :

$$
\mathrm{V}_{\mathrm{t}_{-} \mathrm{wg}}=\frac{V_{\text {axial_wg }}}{\operatorname{Tan}(W G A)},
$$

where $V_{\text {axial } \_ \text {wg }}=$ axial velocity of water at the wicket gate and $\mathrm{WGA}=$ wicket gate angle $\left({ }^{\circ}\right)$. We calculated the tangential velocity at the runner entrance ( $\mathrm{ft} / \mathrm{s}$ ), which according to the law of constant angular momentum, is proportional to the tangential velocity at the wicket gate times the ratio of radial distances out from the center of the runner at the two respective elevations:

$$
V_{t}=\frac{V_{t w g} \cdot r_{0}}{r_{1}}
$$

where $V_{t}=$ tangential velocity at the runner entrance $(\mathrm{ft} / \mathrm{s}), r_{0}=$ radius of an imaginary vertical cylinder with the side touching the downstream tips of wicket gates, and $r_{1}=$ radius of a circle extending out along the blade to where fish passed (i.e., fish-passage radius). There were three wicket-gate-release elevations at Units 5 and 6 at Bonneville Dam in the 1999 and 2000 survival study (high, middle, and low). Model studies have shown that release elevation at the wicket-gate entrance usually determines the passage route of neutrally buoyant particles as follows: high releases pass near the hub, mid-gate releases pass near mid-blade, and low releases pass near the blade tip (USACE 2004). We divided the area swept by runner blades $\left(\mathrm{A}_{\text {Tip }}\right)$ into three equal areas and calculated the average radius for hub, mid, and tip releases $\left(r_{1}=\right.$ R_hub, R_mid, or R_tip) from the radii bounding each successive area (Figure 2; Table 2), using the approach described by Chester Scott in Section III of Bell (1981). For each average fish-passage radius, we estimated the absolute velocity vector $\left(V_{1}\right)$ using:

$$
V_{1}=\left(V_{\text {axial }}^{2}+\mathrm{V}_{\mathrm{t}}^{2}\right)^{0.5}
$$

where $V_{\text {axial }}=$ axial velocity at the runner blades (Table 2), and $\mathrm{V}_{\mathrm{t}}=$ tangential velocity at the runner blades (Figure 3). Next, we estimated the angle between tangential and absolute velocity vectors $(\alpha)$

$$
\alpha=\sin ^{-1}\left(\frac{V_{\text {axial }}}{V_{1}}\right),
$$

where $\sin ^{-1}$ is the arcsin or inverse sine, $V_{\text {axial }}=$ axial velocity (Table 2), and $V_{1}$ is the absolute velocity vector (Figure 3 ). The angle between axial and absolute velocity vectors $(\theta)$ is the complementary angle to $\alpha$ (Figure 3), so $\theta=90-\alpha$. 
Existing Kaplan

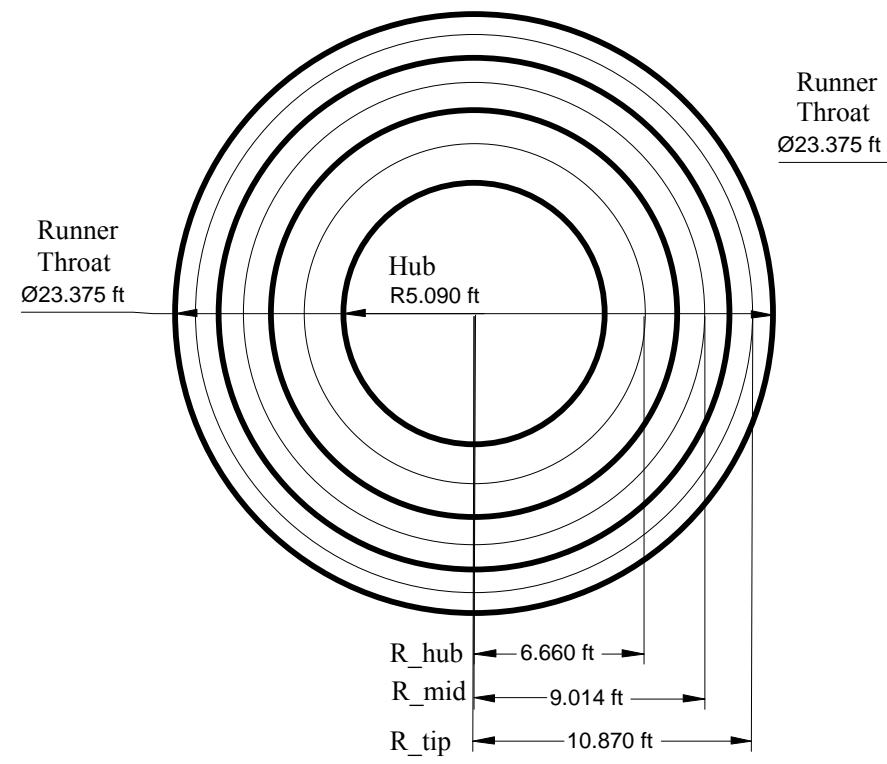

Minimum Gap Runne

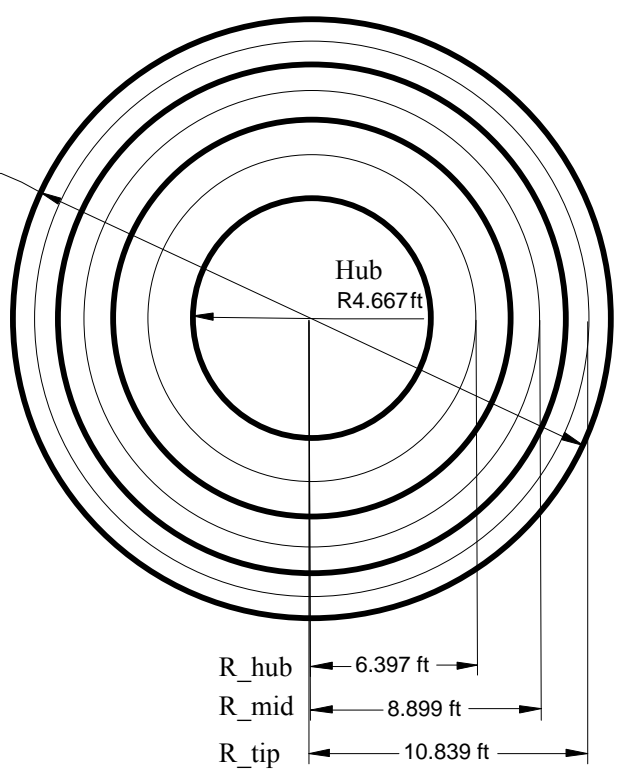

Figure 2. Plan View Showing Radial Dimensions of the Hub and Throat of an Existing Kaplan Turbine at Unit 5 and a New Minimum Gap Runner Turbine at Unit 6 at Bonneville Dam. The area between the runner hub and throat was divided into three equal areas and then the average radius of two at the inner and outer bounds of each area (heavy lines) was calculated (i.e., R_hub, R_mid, and R_tip).

Table 2. Excel Spreadsheet Showing Calculations of Average Radii for Three Equal Areas Between the Hub and the Runner Tip for the Existing Kaplan Runner in Unit 5. Within Microsoft Excel formulas, spreadsheet cells are referenced by combinations of column letters and row numbers, $\operatorname{PI}()=\pi, *=$ multiply,$^{\wedge}=$ raise to the power.

\begin{tabular}{|c|c|c|c|c|c|c|c|c|c|c|}
\hline & $\mathrm{A}$ & $\mathrm{B}$ & $\mathrm{C}$ & D & $\mathrm{E}$ & $\mathrm{F}$ & $\mathrm{G}$ & $\mathrm{H}$ & I & $\mathbf{J}$ \\
\hline 1 & & & & & & & & & & Excel \\
\hline 2 & Abbreviation & Value & \multicolumn{7}{|c|}{ Description } & Formula \\
\hline 3 & $\mathrm{~A}_{\text {Tip }}$ & \multicolumn{8}{|c|}{ 347.741 Area swept by blades } & $=\mathrm{PI}()^{*} \mathrm{~B} 5^{\wedge} 2-\mathrm{PI}()^{*} \mathrm{~B} 8^{\wedge} 2$ \\
\hline 4 & $\mathrm{~A}_{\mathrm{Tip}} / 3$ & \multicolumn{8}{|c|}{ 115.914 Divide in three equal areas } & $=\mathrm{B} 5 / 3$ \\
\hline 5 & $\mathrm{R}_{\text {tip }}$ & \multicolumn{8}{|c|}{11.688 Radius - of blade tips } & Given \\
\hline 6 & $\mathrm{R}_{\text {ipom }}$ & \multicolumn{8}{|c|}{ 9.985 Radius - inside of the peripherial area and outside of the midblade area } & $=\left(\mathrm{B}^{\wedge} 2-(\mathrm{B} 4 / \mathrm{PI}(0))^{\wedge} 0.5\right.$ \\
\hline 7 & $\mathrm{R}_{\text {imoh }}$ & \multicolumn{8}{|c|}{7.925 Radius - inside of the midblade area and outside of the hub area } & $=\left(\mathrm{B} 6^{\wedge} 2-(\mathrm{B} 4 / \mathrm{PI}(0))^{\wedge} 0.5\right.$ \\
\hline 8 & $\mathrm{R}_{\text {hub }}$ & \multicolumn{8}{|c|}{5.090 Radius - of hub } & Given \\
\hline 9 & \multicolumn{10}{|c|}{ Calculate the average radius: } \\
\hline 10 & $\left(\mathrm{~A}_{\mathrm{Tip}} / 3\right) / 2$ & \multicolumn{8}{|c|}{57.957 one half of the each $1 / 3 \mathrm{rd}$ area } & $=\mathrm{B} 4 / 2$ \\
\hline 11 & R_tip & \multicolumn{8}{|c|}{10.870 Mean radius of peripherial area } & $=\left(\mathrm{B}^{\wedge} 2-(\mathrm{B} 10 / \mathrm{PI}(0))^{\wedge} 0.5\right.$ \\
\hline 12 & R_mid & \multicolumn{8}{|c|}{ 9.014 Mean radius of mid-blade area area } & $=\left(\mathrm{B} 6^{\wedge} 2-(\mathrm{B} 10 / \mathrm{PI}())\right)^{\wedge} 0.5$ \\
\hline 13 & R_hub & \multicolumn{8}{|c|}{6.660 Mean radius of the hub area } & $=\left(\mathrm{B} 7^{\wedge} 2-(\mathrm{B} 10 / \mathrm{PI}())\right)^{\wedge} 0.5$ \\
\hline
\end{tabular}




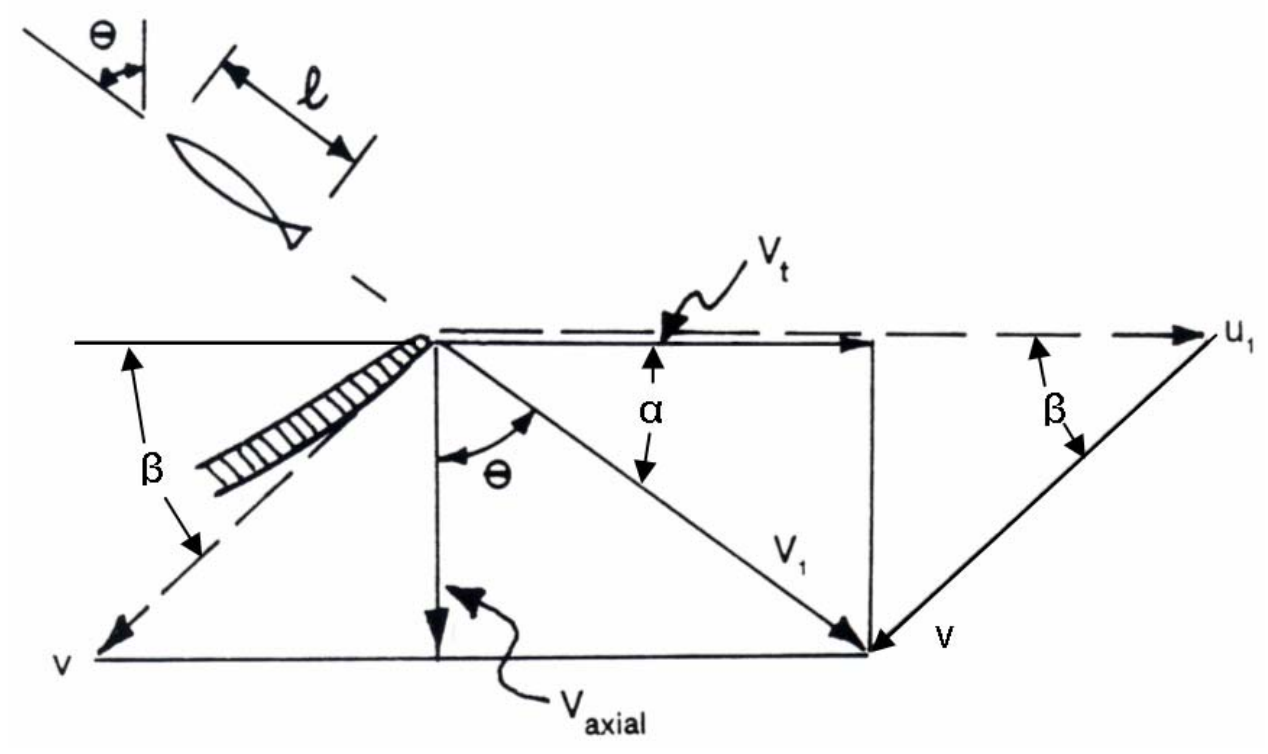

Figure 3. Water Velocity Vector Diagram at the Runner (Bell 1991). The diagram shows a fish of length (1) in flow approaching the leading edge of a runner blade in a Kaplan turbine, velocity vectors, and associated angles. Velocity vectors include $\mathrm{Vt}=$ tangential velocity; $\mathrm{V} 1=$ absolute velocity; Vaxial $=$ axial velocity; $\mathrm{u} 1=$ blade peripheral velocity, and $\mathrm{v}=$ velocity relative to the blade. Angles are as follows: $\alpha=$ the angle between tangential and absolute velocity vectors; $\theta=$ the angle between axial (parallel to the runner axis) and absolute velocity vectors $\left(\theta=90^{\circ}-\alpha\right)$; and $\beta=$ the angle between the horizontal plane and the velocity relative to the blade (v) and is called the "angle of attack."

The deterministic models described above in Equations 1.1-1.5 are widely believed to be logically consistent with what is known of the dynamic characteristics of turbines (Bell 1981). However, the models predict blade strike or strike injury, not fish survival or its inverse (mortality), although we presume that probabilities of blade strike and resulting injury would be correlated with empirical mortality, particularly for blade-tip locations where blade thickness is low and peripheral blade velocity is high.

\subsection{9-2000 Survival Study}

Under the U.S. Army Corps of Engineers Turbine Survival Program, survival probabilities were estimated for 24 treatment groups of hatchery-reared Chinook salmon smolts released into Turbine Units 5 and 6 at Bonneville Dam from November 1999 through January 2000 (Normandeau Associates et al. 2000). Unit 5 was an original Kaplan turbine manufactured in the 1930s; whereas Unit 6 had a new runner designed to minimize the gap between the blade and hub as well as between the blade tip and the discharge ring, and hence was named the MGR. Otherwise, the intake, stay vanes, wicket gates, discharge ring, and discharge tube were identical in both units. The MGR design improves turbine efficiency. The primary objective of the study was to test the hypothesis that the survival of fish that passed through Unit 6 equaled or exceeded that of fish that passed through Unit 5. Secondary objectives included (1) evaluating the effectiveness of gap minimization, (2) better identification of injury mechanisms, (3) looking for correlations between survival 
and operating efficiency and other operating conditions, (4) comparing effects of release locations within turbines, and (5) providing survival estimates within $\pm 3 \%, 90 \%$ of the time.

The study was a factorial design with two turbines, three release locations, and four power levels for 24 distinct treatments. There were four to six replicate releases of fish for every treatment combination. Groups of smolts averaging 6.29 to 6.78 in. long were released through a specially designed induction system to deliver them immediately upstream of a $9.5 \mathrm{ft}$ tall wicket gate at three elevations (high, mid-level, or low) so they presumably would pass near the runner hub, mid-blade, or blade tip, respectively. Control fish were released directly into the tailrace and did not pass through the turbine. All fish were outfitted with balloon and radio telemetry tags to facilitate recovery in the tailwater (Normandeau Associates et al. 2000). Recapture rates of alive and dead fish passed through turbines ranged from $94.6 \%$ to $99.1 \%$ and those of controls released into the tailrace ranged from $97.6 \%$ to $100.0 \%$. The power levels tested at Unit 5 were (1) near the lower end of the $1 \%$ operating efficiency range, (2) slightly below the peak operating efficiency, (3) beyond the peak operating efficiency, and (4) near the upper limit of the $1 \%$ operating efficiency range. The $1 \%$ operating efficiency range of a turbine is a range of generator output (MW) over which the turbine is within $1 \%$ of maximum efficiency. The same power levels were tested for the MGR unit (Unit 6) but with different operating efficiencies because the absolute efficiency of the MGR was greater than or equal to that of the existing unit at all test points. Power levels tested for the MGR unit were (1) below the lower 1\% operating efficiency range, (2) slightly below the peak operating efficiency, (3) beyond the peak operating efficiency but within the $1 \%$ operating efficiency range, and (4) beyond the upper $1 \%$ operating efficiency range. There were four discrete discharges of about $6,200,7,000,10,500$, and 12,000 $\mathrm{ft}^{3} / \mathrm{s}$ that combined with turbine efficiency produced four power-level treatments.

The performance of Kaplan turbines is dependent on the blade-to-gate cam in the governor. For any gate opening and head, there is a unique, optimum blade angle at which efficiency is maximized. Both test units were "tuned" and adjusted with on-cam information developed during field testing in 1999 so that blade angles were optimal for each combination of wicket gate opening and head.

Many metrics of fish injury and survival were estimated in the study, but we used two injury, two mortality, and two combination injury/mortality metrics to compare to model predictions. These were 1) the percent of fish with injuries that were judged to be caused by fluid shear or mechanical forces, 2) with any visually obvious injuries, 3) dead within $1 \mathrm{~h}, 4$ ) dead within $48 \mathrm{~h}, 5$ ) dead or injured, or 6) dead, injured, or with loss of equilibrium. All estimates apply only to the direct effects of the turbine runner and draft tube passage because fish were released between two adjacent stay vanes just upstream of wicket gates. Given the location and orientation of the release tube between stay vanes, fish were unlikely to strike a wicket gate. Indirect effects such as predation were not evaluated. We added shear and mechanical injury percentages together because we doubted that researchers could reliably discriminate between the two types of injury. Odeh (1999) concluded that complex flow field inside the turbine system makes it nearly impossible, without as yet developed instrumentation, to accurately attribute observed fish damage to a specific injury mechanism. Normandeau Associates et al. (2000) judged that most injuries at both turbines were inflicted by shear and mechanical forces, where shear-inflicted injuries were primarily characterized by partial decapitation, hemorrhaged or ruptured eye, and damaged gill or operculum; mechanical injuries were primarily lacerations, severed body or external bruises. 
Daily turbine operations data, including head (ft), wicket gate opening (percent servomotor stroke), blade angle (degrees), power ( $\mathrm{kW})$, efficiency (percent), and discharge $\left(\mathrm{ft}^{3}\right)$ provided by Wittinger and Ramirez (2000) were paired with survival treatment data including release position, power treatment, and replicate number in both reports (Normandeau Associates et al. 2000; Wittinger and Ramirez 2000). We relied heavily on the report by Wittinger and Ramirez (2000) and drawings from Bonneville Dam to obtain specifics about turbine geometry and physics.

\subsection{Deterministic Model Implementation and Evaluation}

In this study, we used a deterministic model (Turnpenny et al. 2000) to predict probabilities of blade strike and injury and compared results with empirical data collected for two Kaplan turbines at Bonneville Dam First Powerhouse (Normandeau Associates et al. 2000) to identify effects and uncertainties. A deterministic model is one that lacks probability, predicting a unique estimate for each combination of input values. Blade-strike predictions were a function of fish length and injection location, runner geometry, runner rotation rate, and axial flow. The model assumes that fish are rigid bodies oriented perpendicular to the leading edge of the blade, and therefore predictions probably are worst case. The model for predicting unadjusted blade-strike probabilities, which would be better characterized as blade encounters that may or may not lead to strike, produced identical results to models formulated by Von Raben (1957), Bell (1991), and Pavlov et al. (2002). As a starting point for our investigation of blade encounter and strike, we used the Turnpenny et al. (2000) model because it also incorporated an empirically derived regression equation for estimating the probability of injury from blade strike. This approach combines the probability of blade-strike and injury into the regression coefficients where the unadjusted blade-strike probabilities are in reality blade encounter probabilities. Other multipleregression models like those of Bell (1991) and Headrick (2001), which predict the survival of turbinepassed fish were considered, but those models were derived from data from many turbines and were not applicable for predicting survival with varying treatments at single turbines. Many of the input variables in those models would be constants when applied to the two Kaplan turbines studied at Bonneville Dam (e.g., number of blades, RPM, circumference/number of blades).

We implemented the deterministic model (Equations 1.5 and 1.6) in a large Microsoft Excel spreadsheet, with one row for each of 118 fish releases in the 1999-2000 survival study (Normandeau Associates et al. 2000). Each row contained cells of data required to classify fish releases according to treatment (unit, power level, release location) and describe runner geometry and operations. Additional cells in a row had data for model inputs or formulas to calculate flow vectors, angles, and other model inputs, as well as formulae to predict probabilities of blade-strike and associated injury. We also added corresponding results from the survival study to remaining columns, which made it easy to explore correlations of predictions with operational variables or with a variety of empirical estimates of injury or mortality. For every replicate release of fish, we calculated 48-h mortality from numbers of control and turbine-passed fish released, recovered alive or dead, or not recovered, as follows:

$$
1-\left[\frac{N_{\mathrm{TA}} \div\left(N_{\mathrm{TR}}-N_{\mathrm{TN}}\right)}{N_{C A} \div\left(N_{C R}-N_{C N}\right)}\right]
$$


where $N=$ number of fish, the first subscript indicates whether fish passed through a turbine ( т) or were released into the tailrace as a control ( $C$ ), and the second subscript describes fish classification, i.e., alive $(A)$, released $(R)$, and not recovered $(N)$. This control-corrected mortality calculation described by Bell (1981) allowed us to compare predicted and empirical results for each turbine with 59 pairs of estimates. We also averaged predictions by treatment to compare with empirical estimates presented by Normandeau Associates et al. (2000). This approach provided 12 pairs of predicted and empirical estimates for each turbine unit. Survival or injury estimates for each of the 59 releases per turbine were not presented in the Normandeau Associates et al. (2000) report; they only presented estimates pooled by treatment (unit, power level 4, and release location).

\subsection{Stochastic Model Implementation}

The stochastic version of the model also was implemented in Microsoft Excel using @Risk software by the Palisade Corporation. The software allows users to define distributions of inputs for any or all independent variables so that predictions have variation that can be quantified. Three variables were assigned distributions of possible values in simulations. Discharge was assigned a uniform distribution ranging from the minimum to the maximum observed for each turbine in the survival study. We also applied distributions for two variables with the greatest uncertainty: fish-passage radius and fish length relative to the leading edge of the runner blade. Fish-passage radius is the radius of a circle with its origin at the center of the runner and its circumference at the location where a fish passed the runner blade.

In the first eight simulations, we used a uniform distribution of values for fish-passage radii ranging from the hub radius to the discharge ring radius so that the model predicted an average injury rate for fish passing at all locations along the blade. In two additional runs, the uniform distributions of fish-passage radii were limited to mid-blade and tip distances to model speculation that near hub releases were not as common because of the location of the terminal end of the release hose (Normandeau Associates et al. 2000).

Although the mean length of released fish in the 1999-2000 study varied little $(6.49 \pm 0.03$ in. $-95 \%$ $\mathrm{CI}$ ), the orientation of individuals passing the runner blades was unknown. A fish is much more likely to be struck if it is oriented perpendicular rather than parallel to the runner blade. Therefore, we applied several normal and uniform distributions of mean relative length to address the range of uncertainty about fish orientation. The 4-in. diameter hoses for releasing fish were attached to a stay vane and oriented within 15 degrees of horizontal at three elevations just upstream of wicket gates. The orientation of the terminal ends of the pipes differed slightly. The end of the uppermost pipe was angled downward about 15 degrees below horizontal. The middle pipe end was horizontal, and the end of the bottom pipe was angled upward about 15 degrees above horizontal. If fish immediately oriented into or with the flow in the second after emerging from a hose, they would have been oriented mostly perpendicular to the leading edge of the runner blade, and their relative length distribution would have been a narrow normal or uniform distribution with a mean similar to actual fish lengths. However, if fish were oriented parallel to the long axis of the hose and maintained that orientation as they passed the runner, they would have been mostly parallel to the leading edge and would have had a short relative length perpendicular to the leading edge, something approaching the depth or width of fish. With the uniform distribution of relative length ranging from 0.75 to 6.78 in., we assumed that fish were tumbling as they passed the runner blade and 
could have any orientation or relative length. We used the @Risk software to examine the sensitivity of model predictions to discharge, relative fish length, and fish-passage radius. 


\subsection{Results}

\subsection{Deterministic Model Predictions}

Predictions of the probability of blade strike and blade-strike injury were highly correlated (Figure 4), and predictions of blade-strike injury were inversely and most highly correlated with variables related to turbine discharge and steep blade angles from horizontal (Table 3). Fish-passage radius (previously defined in Section 2.5) was correlated with the probability of strike at a $20 \%$ level of significance for Unit $5(\mathrm{r}=0.195 ; \mathrm{P}=0.139 ; \mathrm{N}=59)$ and at a $5 \%$ level for Unit $6(\mathrm{r}=0.321 ; \mathrm{P}=0.013 ; \mathrm{N}=59)$. Similar correlations were obtained for fish-passage radius with strike injury (Unit 5: $\mathrm{r}=0.171 ; \mathrm{P}=0.195 ; \mathrm{N}=$ 59; and Unit 6: $\mathrm{r}=0.297 ; \mathrm{P}=0.022 ; \mathrm{N}=59$ ).

Correlations indicate that the probability of blade-strike injury increases as efficiency and discharge decrease over the lower part of the generation range, but blade-strike injury decreases as efficiency decreases and discharge increase over the upper part of the generation range. The generation range can be divided into two parts below and above peak efficiency. Predictions of blade-strike injury were inversely correlated with turbine efficiency for the lower one half of the power generation range below the peak operating efficiency level of Unit $5(\mathrm{r}=-0.49 ; \mathrm{P}=0.0071 ; \mathrm{N}=29)$ and Unit $6(\mathrm{r}=-0.33 ; \mathrm{P}<0.0788 ; \mathrm{N}=$ 30). In contrast, predictions of blade-strike injury were positively correlated with turbine efficiency for the upper end of the power generation range above the peak operating efficiency level of Unit $5(\mathrm{r}=0.73$; $\mathrm{P}<0.0001 ; \mathrm{N}=30)$ and Unit $6(\mathrm{r}=0.76 ; \mathrm{P}<0.0001 ; \mathrm{N}=29)$. Probabilities of blade-strike and related injury were not correlated with head (forebay elevation minus tailwater elevation).

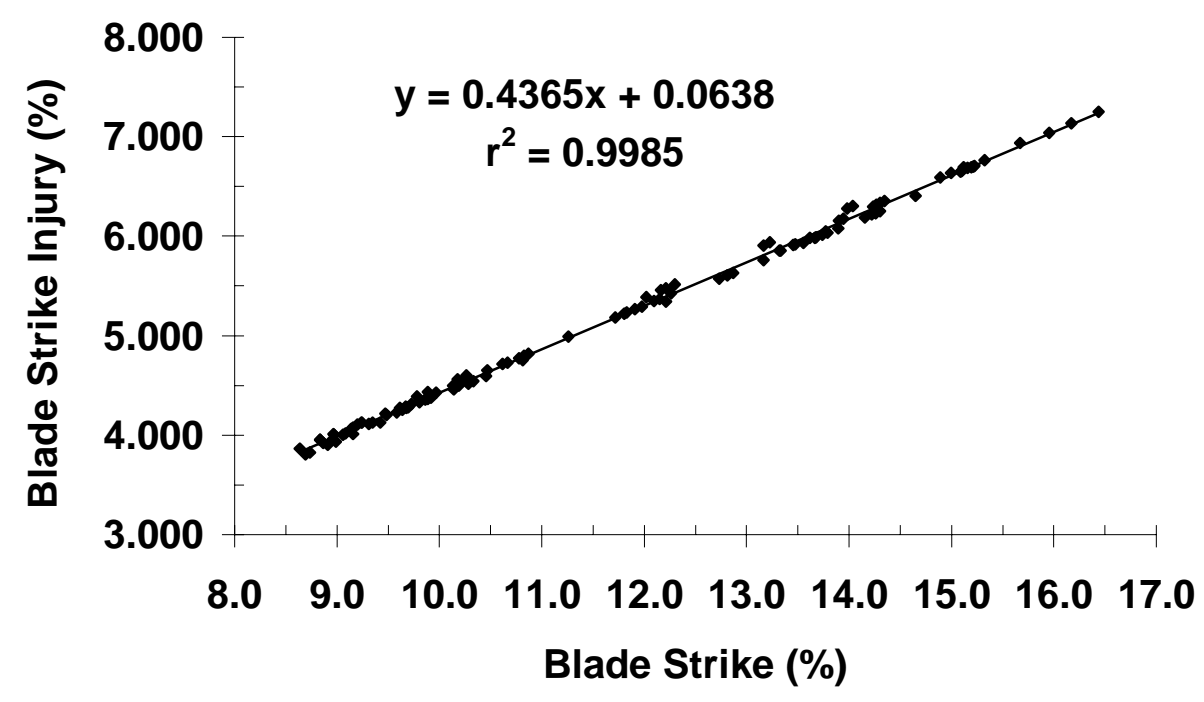

Figure 4. Regression of the Probability of Blade-Strike Injury on the Probability of Blade Strike. 
Table 3. Coefficients of Correlations of Blade Strike and Blade-Strike Injury with Flow-Related Independent Operational Variables from the 1999-2000 Study.

\begin{tabular}{|c|c|c|c|c|c|c|}
\hline Prediction & $\begin{array}{l}\text { Wicket Gate } \\
\text { Position, \% } \\
\text { Servomotor }\end{array}$ & $\begin{array}{c}\text { Blade } \\
\text { Angle }\left({ }^{\circ}\right) \\
\end{array}$ & $\begin{array}{l}\text { Axial Velocity } \\
\text { at the Runner } \\
(\mathrm{ft} / \mathrm{s})\end{array}$ & $\begin{array}{c}\text { Absolute } \\
\text { Velocity at the } \\
\text { Runner (ft/s) }\end{array}$ & $\begin{array}{c}\text { Discharge } \\
\left(\mathrm{ft}^{3 / \mathrm{s}}\right)\end{array}$ & $\begin{array}{c}\text { Power } \\
(\mathrm{kW})\end{array}$ \\
\hline \multicolumn{7}{|l|}{ Unit $5(\mathrm{~N}=59)$} \\
\hline Blade strike & -0.937 & -0.960 & -0.957 & -0.983 & -0.957 & -0.949 \\
\hline Blade-strike injury & -0.945 & -0.961 & -0.958 & -0.978 & -0.958 & -0.950 \\
\hline \multicolumn{7}{|l|}{ Unit $6(N=59)$} \\
\hline Blade strike & -0.913 & -0.910 & -0.921 & -0.988 & -0.921 & -0.910 \\
\hline Blade-strike injury & -0.923 & -0.916 & -0.929 & -0.983 & -0.929 & -0.919 \\
\hline
\end{tabular}

The best multiple regression models for predicting the probability of strike from observed data $(\mathrm{N}=59)$ were as follows:

$$
\begin{aligned}
& P_{\text {Strike }}=-0.00095413(\mathrm{Q})+0.02414\left(\mathrm{R}_{\text {Fish }}\right)+17.69173\left(\text { Unit } 5 ; \mathrm{R}^{2}=0.95 ; \mathrm{P}<0.0001\right) \text { and } \\
& P_{\text {Strike }}=-0.00080885(\mathrm{Q})+0.03161\left(\mathrm{R}_{\text {Fish }}\right)+15.57141\left(\text { Unit } 6 ; \mathrm{R}^{2}=0.96 ; \mathrm{P}<0.0001\right),
\end{aligned}
$$

where $\mathrm{Q}=$ discharge $\left(\mathrm{ft}^{3} / \mathrm{s}\right)$ and $\mathrm{R}_{\text {Fish }}=$ fish-passage radius. Similar relations were obtained for the probability of injury from blade strike:

$$
\begin{aligned}
& P_{\text {Injury }}=-0.00041987(\mathrm{Q})+0.00934\left(\mathrm{R}_{\text {Fish }}\right)+7.94513\left(\text { Unit 5; } \mathrm{R}^{2}=0.95 ; \mathrm{P}<0.0001\right) \text { and } \\
& P_{\text {Injury }}=-0.00035284(\mathrm{Q})+0.01269\left(\mathrm{R}_{\text {Fish }}\right)+6.98033\left(\text { Unit 6; } \mathrm{R}^{2}=0.96 ; \mathrm{P}<0.0001\right) .
\end{aligned}
$$

The response surface the last two equations are shown in Figure 5. The range in fish-passage radii ( $\mathrm{R} \_$Fish) is from the hub radius to the tip radius ( $\mathrm{R}$ _hub and $\mathrm{R}$ _tip as described in Figure 2).

A significant unit-discharge interaction indicated that slopes of the regression lines between bladestrike probability and turbine discharge for the two turbines differed significantly (Figure 5). A similar trend was observed for predicted probabilities of blade-strike injury. Average predicted probabilities of blade strike were slightly higher for Unit 5 (Kaplan) than for Unit 6 (MGR) at low discharge, but the opposite was true at high discharge (Figures 6 and 7).

\subsection{Model Predictions Versus Empirical Results}

Over the full range of power (discharge) treatments, the average prediction of blade-strike injury was 2-5 times higher than average empirical estimates of shear + mechanical injury or visible injury, and overestimates were highest for fish that passed near the hub (Figure 8). For fish passing at mid-blade or near the tip, most average predictions of blade-strike injury were similar to average empirical estimates of 1-h and 48-h mortality, rates for dead or injured fish, or rates for fish classified as dead, injured, or without equilibrium. 
Unit $=6$

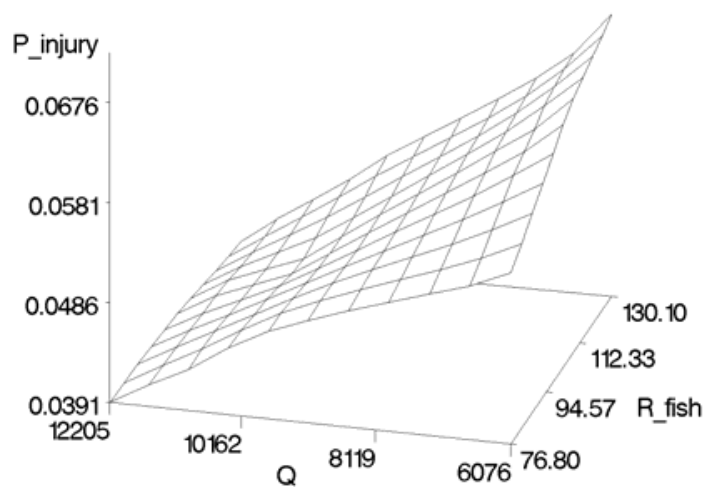

Unit $=5$

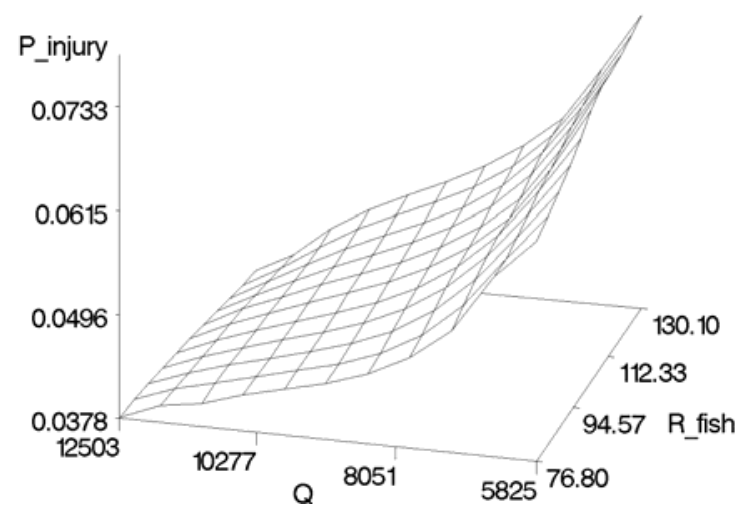

Figure 5. Response Surface of the Probability of Injury ( $\mathrm{P}$ injury) from Blade Strike Relative to Discharge $\left(\mathrm{Q}\right.$ in $\left.\mathrm{ft}^{3 / \mathrm{s}}\right)$ and Fish-Passage Radius ( $\mathrm{R}$ _fish in inches) at an Existing Kaplan (left) and a New Minimum-Gap-Runner Kaplan (right)

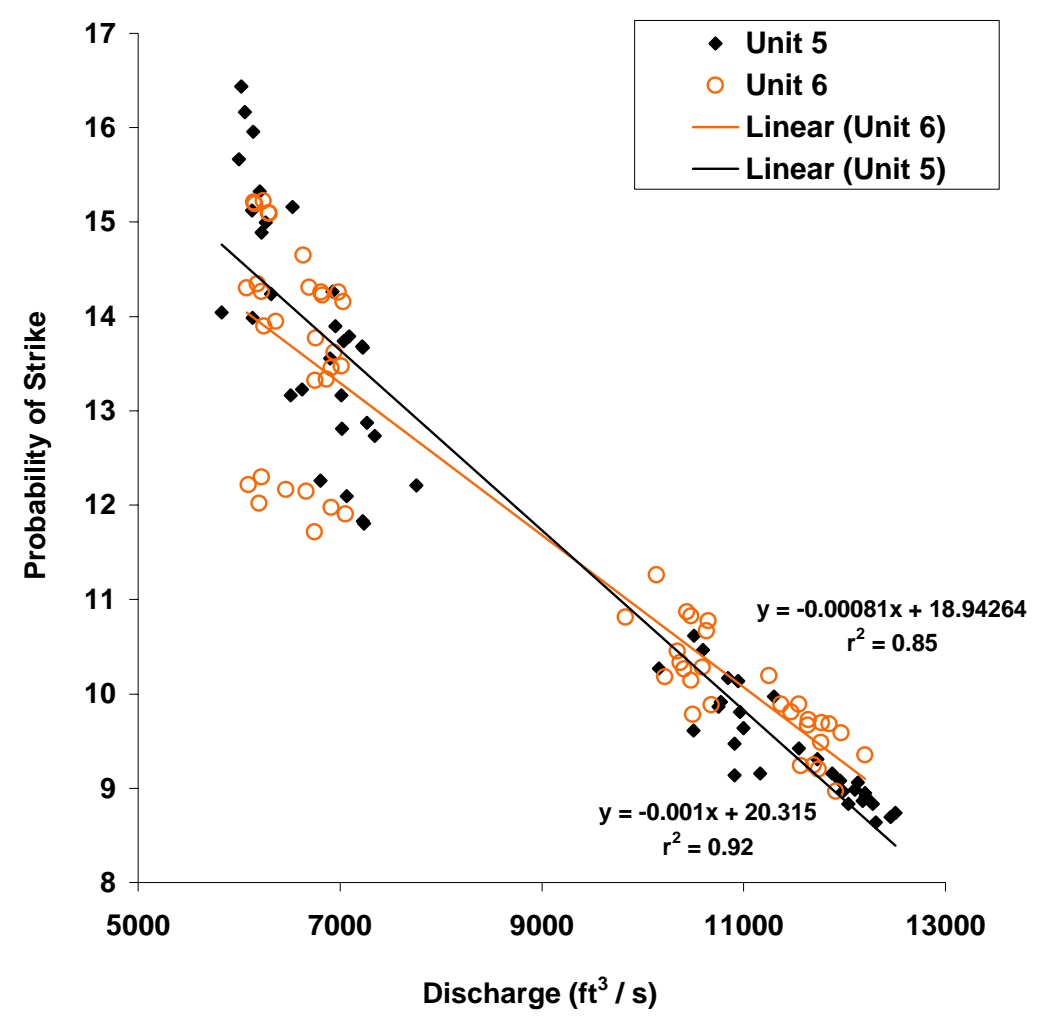

Figure 6. Plot of Predictions of Blade Strike as a Function of Discharge for Unit 5 (Existing Kaplan) and Unit 6 (Kaplan with MGR) 


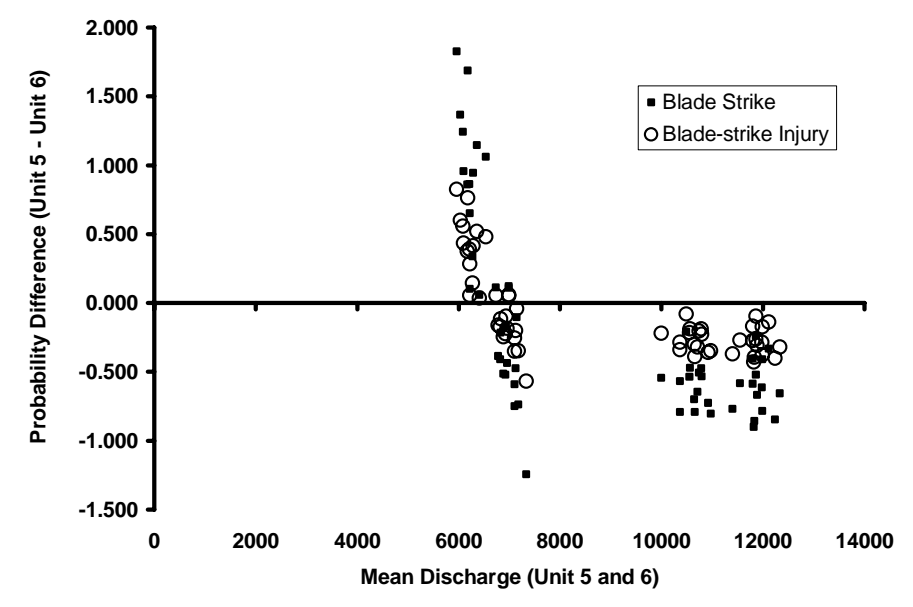

Figure 7. Among-Unit Differences in Probabilities of Blade Strike Displayed as a Function of Mean Discharge. Probabilities Were Greater for Unit 5 than for Unit 6, with the Minimum Gap Runner, only when Discharge was $<$ About $7,000 \mathrm{Ft}^{3 / \mathrm{S}}$

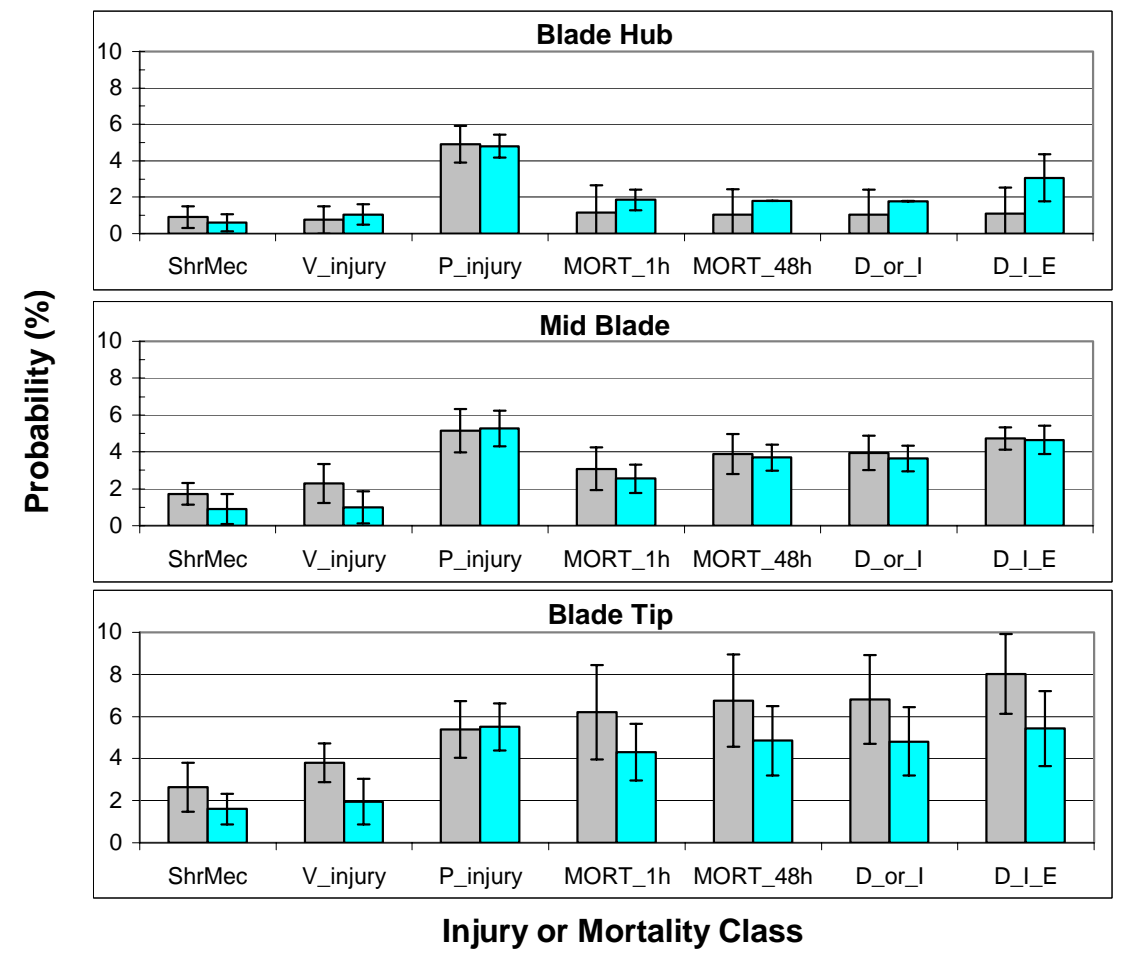

Figure 8. Bar Chart Comparing Probabilities of Predicted Blade-Strike Injury (P_injury) with Empirical Estimates of Shear + Mechanical Injury (ShrMec), Visible Injury (V_injury), 1-h Mortality (MORT_1 h), 48-h Mortality (MORT 48 h), Dead or Injured (D_or_I), or Dead, Injured, or Loss of Equilibrium (D_I_E) for Unit 5 (gray bars) and Unit 6 (blue bars). Error bars are $95 \%$ confidence intervals calculated as standard errors 1.96 . 
Over the full range of discharge, none of the among-unit differences in model predictions of bladestrike injury or of the empirical estimates of injury and mortality appeared to differ significantly based upon overlap of 95\% confidence intervals (Figure 8). The Normandeau Associates et al. (2000) study found no significant differences in 1-h survival, 48-h survival, or the death, injury and equilibrium-loss metric between the turbines ( $\mathrm{P}>0.05)$, and this result also is suggested by confidence intervals in Figure 8 . However, they did find that mortality estimates for blade-tip released fish in Unit 5 were significantly higher by about 3\% than those for fish passing the blade tip in Unit 6 . A similar trend was observed for fish passing at mid-blade but only at the lowest of four discharge levels (Normandeau Associates et al. 2000). Empirical mortality and injury estimates did not differ between the units for fish passing near the hub or at mid-blade (except at the lowest discharge level).

The most important factor affecting empirical estimates of mortality and injury was release location (Normandeau Associates et al. 2000). This also was a driving variable affecting model predictions (see fish-passage radius in Figure 5). The release location determined whether a test fish would pass near the tips, middle, or hub of turbine runner blades. Peripheral blade velocity at the fish-passage radius also was a highly significant correlation with empirical estimates of mortality and injury, but it was not used in stepwise regression models because it was very highly correlated with fish-passage radius and was more complicated to calculate.

Simple linear models that had fish-passage radius as an independent variable explained the greatest proportion of variation in empirical estimates (Table 4), although many operational variables were included in stepwise-regression models. Other independent variables included head, blade angle, wicket gate position (percent servomotor), power, discharge, and efficiency (after Normandeau Associates et al. 2000); head squared, plant sigma, specific speed, wicket gate position squared, specific speed squared

Table 4. Stepwise Regression Models for Predicting Empirical Estimates of Injury or Mortality from Normandeau Associates et al. (2000). Other than the models listed, no other independent variables met the inclusion criteria (partial probability $<0.15$ ). Models have the form $y=a(x)$ $+\mathrm{c}$, where $\mathrm{y}=$ dependent variable, $\mathrm{a}=1$ st coefficient, $\mathrm{x}=$ independent variable, and $\mathrm{c}=\mathrm{y}$ intercept. Other variables include $\mathrm{R}_{-}$fish $=$fish passage radius, and $\mathrm{r}^{2}=$ coefficient of determination.

\begin{tabular}{||c|l|c|c|c|c|c||}
\hline \hline Unit & \multicolumn{1}{|c|}{$\mathrm{y}$} & $\mathrm{a}$ & $\mathrm{x}$ & $\mathrm{c}$ & $\mathrm{r}^{2}$ & $\mathrm{P}$ \\
\hline \hline 5 & Shear + mechanical injury & 0.03394 & R_fish & -1.85430 & 0.48 & 0.0039 \\
\hline 5 & Visual injuries & 0.06016 & R_fish & -4.10503 & 0.69 & 0.0007 \\
\hline 5 & Dead or injured & 0.11390 & R_fish & -8.16759 & 0.74 & 0.0003 \\
\hline 5 & Dead, injured, or lost equilibrium & 0.13637 & R_fish & -9.86711 & 0.84 & $<0.0001$ \\
\hline 5 & 1-h Mortality & 0.09858 & R_fish & -6.99324 & 0.63 & 0.0020 \\
\hline 5 & 48-h Mortality & 0.11232 & R_fish & -8.03503 & 0.72 & 0.0005 \\
\hline 6 & Shear or mechanical injury & 0.01835 & R_fish & -0.88553 & 0.29 & 0.0687 \\
\hline 6 & Visual injuries & & & & & $>0.1500$ \\
\hline 6 & Dead or injured & 0.05725 & R_fish & -2.57324 & 0.65 & 0.0014 \\
\hline 6 & Dead, injured, or lost equilibrium & 0.04500 & R_fish & -0.32756 & 0.40 & 0.0266 \\
\hline 6 & 1-h Mortality & 0.04490 & R_fish & -1.79549 & 0.54 & 0.0064 \\
\hline 6 & 48-h Mortality & 0.05751 & R_fish & -2.56362 & 0.65 & 0.0015 \\
\hline
\end{tabular}


(after Bell et al. 1981), and our estimates of fish-passage radius, water velocity vectors at the runner (axial, absolute, tangential), vector angles alpha, beta, and theta (Figure 3), and predictions of blade strike and blade-strike injury. Unlike blade-strike-model responses (Figure 5; Table 3), none of the stepwise regressions of empirical injury or survival estimates on discharge, head, wicket gate position, blade angle, generation, or efficiency by turbine and release position was significant (Normandeau Associates et al. 2000). We also found no significant $(\mathrm{P}<0.05)$ regressions of empirical estimates of injury or mortality on predicted blade-strike injury. However, at $\mathrm{P}=0.15$, the percent of fish that were dead, injured, or lacked equilibrium was significantly correlated with predictions of strike $(\mathrm{r}=0.49 ; \mathrm{P}=0.1051 ; \mathrm{N}=12)$ and strike-injury ( $\mathrm{r}=0.47 ; \mathrm{P}=0.1239 ; \mathrm{N}=12)$. Other potential variables used by Bell et al. (1981) and Headrick (2001) in among-turbine analyses (e.g., RPM and number of blades) were constants for the two Bonneville turbines and therefore not included as independent variables.

Normandeau Associates et al. (2000) found that survival between hub-released and mid-blade release locations did not differ significantly, but that estimates of absolute survival could be categorized as having an increasing gradient from blade tip to mid-blade to hub. The terminus of the pipe for hub releases may have actually passed fish some distance away from the hub and along the mid-blade region (USACE 2004). This may explain non-significant differences between hub and mid-blade releases. Normandeau Associates et al. (2000) stated that this was supported by low fish-injury rate and highsurvival rate in Unit 5 and the absence of pinching type injuries typical of gap-related damage. Few hubreleased fish were injured in either turbine $(0.7 \%$ for Unit 5 and $1.0 \%$ for Unit 6$)$.

\subsection{Stochastic Model}

Eight runs of the stochastic model, each with different assumptions about the distribution of fish lengths relative to the leading edge of the runner blades, showed that predicted injury rates and the dependence of predictions on discharge decreased as mean length decreased (Figure 9) or as the range in mean length increased (Figure 9). Empirical results showed no effect of discharge on rates of injury or mortality (Normandeau Associates et al. 2000). Predicted rates of injury for fish with the shortest mean relative length or with the widest distribution of relative length were $1.9 \pm 0.75 \% \mathrm{SE}$ and $2.4 \pm 1.6 \% \mathrm{SE}$, respectively (see the bottom panels of Figures 9 and 10). These predictions were closer to the range of empirical rates of total visible injury or shear + mechanical injury than predictions from the deterministic model (Figure 8), particularly for mid-blade and tip-released fish. The deterministic model runs assumed that all fish were oriented perpendicular to the leading edge of the runner blade. Injury predictions were comparable to empirical injury rates in simulations with the full range of discharge (Uniform 5825-12503 $\mathrm{ft}^{3} / \mathrm{s}$ at Unit 5 and Uniform 6076-12205 $\mathrm{ft}^{3} / \mathrm{s}$ at Unit 6), fish passage radius limited to mid-blade to tip distances, and fish lengths defined by either a normal distribution (mean $=3.25$ in., $\sigma=0.8$ ) or a uniform (random) distribution as shown in Figure 11 (Uniform distribution ranging from 0.75 to 6.78 in.). Fishpassage radius was randomly varied from 93 to $140.24 \mathrm{in}$. 

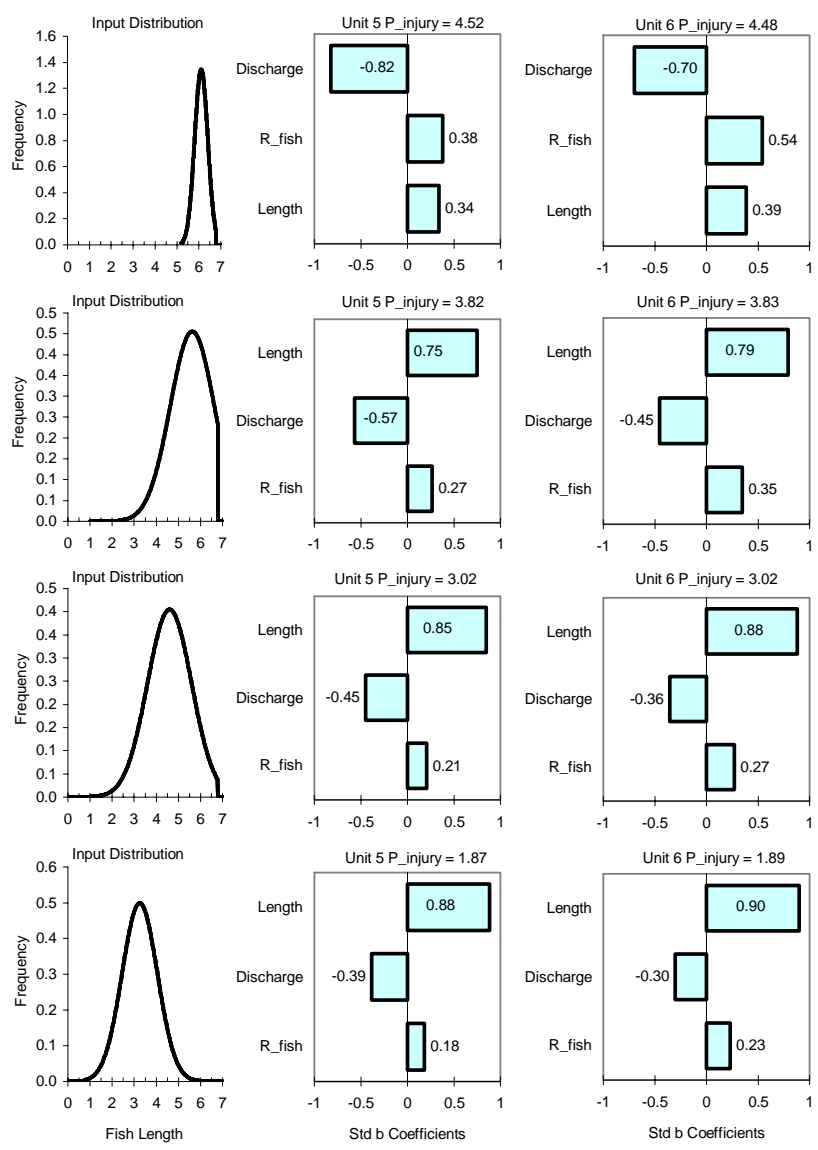

Figure 9. Plots of Various Normal Input Distributions of Relative Fish Length (left) and Standardized Regression Coefficients (right) that Indicate the Sensitivity of Injury Predictions (P_injury) to Fish Length, Turbine Discharge, and Fish-Passage Radius (R_fish). Mean predicted percentages of fish injured are presented above each sensitivity plot. 

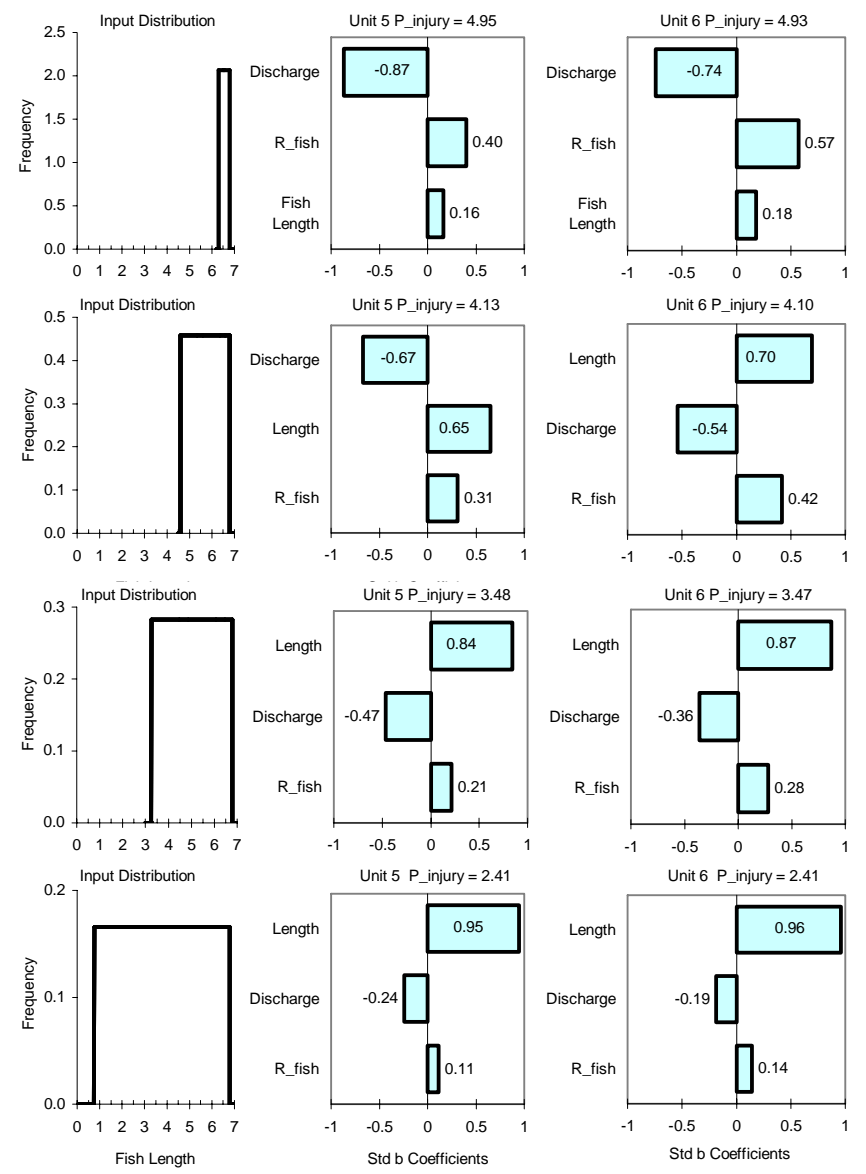

Figure 10. Plots of Various Uniform Input Distributions of Relative Fish Length (left) and Standardized Regression Coefficients (right) that Indicate the Sensitivity of Injury Predictions (P_injury) to Fish Length, Discharge, and Fish-Passage Radius (R_fish). Mean predictions are presented above each sensitivity plot.

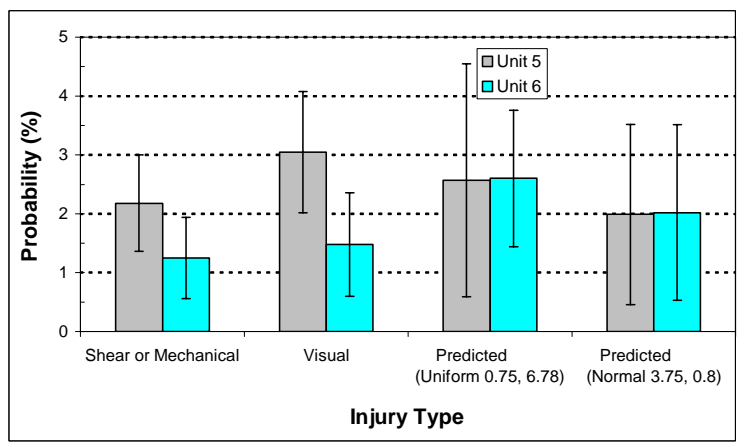

Figure 11. Comparison of Empirical and Predicted Injury Probabilities for Fish Passing from the MidBlade to the Tip of Runner Blades. Error bars are $95 \%$ confidence intervals about the means. 


\subsection{Discussion}

The high correlation of probabilities of blade-strike injury with blade strike resulted from a nearly constant mutilation ratio $(0.4421 \pm 0.0006-95 \% \mathrm{CI})$. This ratio was very close to the 0.43 ratio observed by Von Raben (1957), although the rate can range from near 0.0 to 5.6 (Turnpenny et al. 2000) if fish length varies widely. The ratio is calculated from mean fish length (Equation 1.6), which varied little among releases of hatchery fish by Normandeau Associates et al. 2000 (6.29 in. -6.78 in.).

Fish orientation relative to the leading edge of the runner blades appears to be one of the greatest uncertainties in blade-strike modeling, and orientation may explain why turbine discharge, which was the most significant factor affecting predicted strike and injury, was not significantly correlated with empirical estimates of injury or mortality. When we assumed that fish were oriented perpendicular to the leading edge of the runner blades, discharge was the most important factor affecting injury predictions, and predictions were 2-5 times higher than empirical estimates of shear + mechanical injury or visual injury. When we assumed fish were oriented with their long axis within 30 degrees of the leading edge of the blade instead of perpendicular to it, mean relative length decreased to one half of the actual length, discharge became much less important than relative length, and predictions of injury did not differ from empirical estimates. We obtained similar results by assuming that fish exited the release hoses and tumbled as they passed the runner blades.

The importance of discharge as a driving variable decreased as relative fish length decreased or as the range of relative length increased. Given the nearly horizontal orientation of the ends of the release pipes in the survival study, we believe it is very unlikely that 6.3 to 6.8 -in. fish would emerge from the 4-in. diameter pipe and instantly orient parallel to flow and perpendicular to the runner blades by shifting their body axis $>45$ degree in $<1 \mathrm{~s}$. We recommend renewed efforts to videotape fish passing between the wicket gate and the top of the runner blade to assess fish orientation relative to flow and to the leading edge of blades. Direct visual observations are not available to correlate mortality to strike (USACE 1995), and data on specific causes of mechanical injury to fish passing through turbines are very limited and do not consistently agree with model predictions (Odeh 1999).

Another reason that a significant correlation of empirical estimates of fish injury and mortality with turbine discharge was lacking is that other factors may increase injury and mortality as discharge increases and mask a reduction in blade-strike injury. For example, Garrison et al. (2002) predicted shear-related mortality that appeared to increase with discharge. This apparently did not compare well with the fish survival data from Wanapum Dam, but the authors concluded that fish probably were not evenly distributed throughout the flow channel or were distributed according to flow rate only. Their data also suggested that factors besides shear stress may be playing a large part in fish mortality, and they concluded that fish trajectories are a critical unknown. The probability of injury from increased rates of pressure change also increases with increasing discharge and could be another masking effect. Fish may even be drawn into gap areas by low pressure caused by jet flow through gaps (Garrison et al. 2002). Damage due to pressure is dependent on the amount and rate of change of pressure experienced by the fish as well as the type of the fish (Čada et al. 1997; Odeh 1999). Physostomous fishes like Salmonidae 
have a duct that connects the swim bladder to the esophagus so that they can rapidly take in or vent gas, whereas physoclist fishes like Centrarchidae and Percidae must adjust gas content by slow diffusion into the blood (Lagler et al. 1962).

For fish entrained from a forebay into a turbine, the vertical distribution of fish at the wicket gate is another critical uncertainty for modeling injury probabilities. Using physical models, the Engineering Research and Development Center established that passage elevation at the wicket gate is correlated with passage location along the runner blade (USACE 2004). Fish at higher elevations pass near the hub and those at low elevations pass near the blade tip. However, we do not know how the in-turbine vertical distribution of fish $30 \mathrm{ft}$ upstream of the wicket gates and just downstream of trash racks translates into the vertical distribution at the wicket gate. Using acoustic telemetry to track fish released just below the tip of a submerged traveling screen at McNary Dam, Carlson (2002) observed that most fish passed into the lower one half of the wicket-gate opening. As a result, these fish would be expected to pass from mid-blade out to the runner tip and have higher injury rates than fish passing into the upper one half of the wicket gate opening. If screens were not present, and most fish passed above the elevation of the screen tip, would injury and mortality rates decline because more fish passed from the hub to mid-blade than from mid-blade to the blade tip? Studies should be conducted to determine whether the vertical distribution of fish downstream of trash racks provides a reasonable estimate of vertical distributions at the wicket gates.

Empirical data from the survival study indicated that mortality of blade-tip released fish was higher at Unit 5 than at Unit 6 . Model predictions of injury showed a similar trend for fish passing at all locations, but only at low discharge levels $<8,000 \mathrm{ft}^{3} / \mathrm{s}$. For mid-blade released fish, empirical data showed significantly higher mortality at Unit 5 than at Unit 6 only at the lowest discharge (like the model predictions of injury) while differences at all higher discharge levels were not significant. No empirical differences in mortality between units were significant for fish passing near the hub. Predicted injury was higher at Unit 6 than at Unit 5 at discharges from 8,000 to $12,500 \mathrm{ft}^{3} / \mathrm{s}$, just the opposite of mortality trends observed in the survival study for fish passing the blade tip. During high power-level treatments, the discharge through Unit 5 averaged 500 cubic feet per second $>$ the discharge through Unit 6 . This is sufficient to explain lower predicted injury probability at Unit 5 than at Unit 6 . This difference in average discharge probably was responsible for a significant unit $\times$ discharge interaction in model predictions that was not apparent in the empirical data collected by Normandeau Associates et al. (2000). The inability of researchers to accurately assign causal mechanisms to observed injuries may be responsible for ambiguous results relating injury or mortality to discharge in the survival study. For example, the frequency of blade-strike injuries could decline with increasing discharge but remain undetectable if lumped with injuries resulting from other causes that are positively correlated with discharge.

Both predicted and empirical estimates of injury and mortality were positively correlated with fishpassage radius, but in the empirical data set, fish-passage radius was the only significant variable correlated with injury or survival (Normandeau Associates et al. 2000). In deterministic models, fishpassage radius was of secondary importance to discharge and relative fish length, whenever relative length varied widely. In the blade-strike model, the effect of fish-passage radius is buried in the calculation of tangential velocity at the runner (Equation 1.7), which is a component for estimating the angle $\theta$ and eventually water length in Equation 1.5. It is also part of the calculation of peripheral blade 
velocity at the location where a fish passed, which we found to be an important correlation with empirical estimates of injury, although peripheral blade velocity is not explicitly part of the blade-strike model.

Data from Eicher et al. (1987) indicated that mortality increases with runner peripheral velocities and that more strikes would occur at higher tip speeds. The effect of fish-passage radius in the model probably would be stronger if blade thickness was considered in addition to velocity, but it is not. The thicker portion of the runner blade near the hub has a lower relative velocity and exerts more drag on the surface of fish than does the thin portion of the blade near the runner tip. Drag on the surface of a fish will pull a fish around the blade when it exceeds the inertial forces of the fish and runner blade (Turnpenny et al. 2000).

Differences in relative blade velocities may explain why predictions of injury were within $2-3 \%$ of empirical 48-h mortality estimates for fish passing at mid-blade and tip locations (Figure 8) but were 6-8 $\%$ higher than 48-h mortality estimates for hub-passed fish. Mortal injuries are more likely to result when relative blade velocities are high like those at mid-blade and tip locations. Empirical estimates of mortality may be better metrics for comparison to predicted injury rates than empirical estimates of shear and mechanical injury or visual injury for fish passing at mid-blade and blade-tip locations.

This study is the initial stage of further investigation into the dynamics of injury to fish during passage through a turbine runner. We intend to extend the model by including more realistic treatment of the physics of encounters between fish and turbine blades. It should be possible to estimate the probability of strike and features of impact dynamics upon encounter based on physical arguments alone thereby reducing model coefficients which must be empirically estimated to those dependent upon the biological factors influencing whether a fish is injured or killed when struck. It is likely that better understanding of aspects of blade strike and impact dynamics will lead to injury mechanics hypotheses that can be tested under laboratory conditions using accepted biomechanics study methods. 


\subsection{References}

Amaral S., T. Cook, G. Hecker, and M. Metzger. 2003. Biological Evaluation of the Alden/Concepts NREC Turbine. Waterpower XIII, Buffalo.

Bell, M.C. 1981. Updated Compendium of the Success of Passage of Small Fish Through Turbines. Report to the U.S. Army Corps of Engineers, North Pacific Division, Portland, Oregon.

Bell, M.C. 1991. Revised Compendium of the Success of Passage of Small Fish Through Turbines. Report to the U.S. Army Corps of Engineers, North Pacific Division, Portland, Oregon.

Čada G.F., C.C. Coutant, and R.R. Whitney. 1997. Development of Biological Criteria for the Design of Advanced Hydroturbines. U.S. Department of Energy, Idaho Operations Office, DOE/ID-10578, Idaho Falls, Idaho.

Carlson, T.J. 2002. Ultrasonic 3-D Tracking of Fish and Drogues Passing Through a Kaplan Turbine Intake at McNary Dam, 1999 \& 2000. PNWD-3128, Battelle, Pacific Division, Richland, Washington.

Carlson, T.J., and J.P. Duncan. 2003. Evolution of the Sensor Fish Device for Measuring Physical Condition in Severe Hydraulic Environments. U.S. Department of Energy, Idaho Operations Office, DOE/ID-11079, Idaho Falls, Idaho.

Coutant, C.C., and R.R.Whitney. 2000. "Fish behavior in relation to passage through hydropower turbines: A review." Transactions of the American Fisheries Society 129:351-380.

Eicher, G.J., C.J. Campbell, R.E. Craven, and M.A. West. 1987. Turbine Related Fish Mortality:

Review and Evaluation of Studies. Report No. EPRI AP-5480, Electric Power Research Institute, Palo Alto, California.

Garrison, L.A., R.K. Fisher, Jr., M.J. Sale, and G.F. Čada. 2002. “Application of Biological Design Criteria and Computational Fluid Dynamics to Investigate Fish Survival in Kaplan Turbines." HydroVision 2002, HCI Publications, Kansas City, Missouri.

Headrick, M.R. 2001. "Predicting fish survival in axial flow turbines." Hydro Review 20(4):114-119.

Lagler, K.F., J.E. Bardach, and R.R. Miller. 1962. Ichthyology. John Wiley \& Sons, New York.

Monten, E. 1985. Fish and Turbines: Fish Injuries During Passage Through Power Station Turbines. Vattenfall, Sweden.

Normandeau Associates, Inc., J.R. Skalski, and Mid-Columbia Consulting, Inc. 2000. Direct Survival and Condition of Juvenile Chinook Salmon Passed Through an Existing and New Minimum Gap Runner Turbines at Bonneville Dam First Powerhouse, Columbia River. Report to U.S. Army Corps of Engineers, Portland District, Portland, Oregon. 
Odeh, M. 1999. A Summary of Environmentally Friendly Turbine Design Concepts (Concepts Developed by Alden Research Laboratory, Inc., Voith Hydro, Inc. and their Teams). Report DOE/ID13741 prepared by the United States Geological Survey for the U.S. Department of Energy, Idaho Operations Office, Idaho Falls, Idaho.

Pavlov, D.S., A.I. Lupandin, and V.V. Kostin. 2002. Downstream Migration of Fish Through Dams of Hydroelectric Power Plants. Trans. T. Albert, trans. ed. G. F. Čada. ORNL/TR-02/02, Oak Ridge National Laboratory, Oak Ridge, Tennessee.

Solomon, D.J. 1988. Fish Passage Through Tidal Energy Barrages. Final Report. Energy Technical Support Unit, Harwell, United Kingdom.

Stone and Webster Environmental Services. 1992. Fish Entrainment and Turbine Mortality Review and Guidelines. Electric Power Research Institute, EPRI TR-101231, Palo Alto, California.

Tikhij, M.V., and P.V. Viktorov. 1940. Fish Resources and HPP Construction. M.: Pithsepromizdat, $200 \mathrm{p}$.

Turnpenny, A.W.H. 1998. Mechanisms of Fish Damage in Low-Head Turbines: An Experimental Appraisal. In Fish Migration and Fish Bypasses, eds. M. Jungwirth, S. Schmutz, and S. Weiss, pp. 300314. Fishing News Books, Blackwell Publishing, Oxford, United Kingdom.

Turnpenny, A.W.H., D.M. Davis, J.M. Fleming, and J.K. Davies. 1992. Experimental Studies Relating to the Passage of Fish and Shrimps Through Tidal Power Turbines. National Power PLC, Fawley, Hampshire, United Kingdom.

Turnpenny, A.W.H., S. Clough, K.P. Hanson, R. Ramsay, and D. McEwan. 2000. Risk Assessment for Fish Passage Through Small, Low-Head Turbines. Final Report. Energy Technical Support Unit, Harwell, United Kingdom.

U.S. Army Corps of Engineers (USACE). 1995. Proceedings of the Turbine Fish Passage Survival Workshop. U.S. Army Corps of Engineers, Portland District, Portland, Oregon.

U.S. Army Corps of Engineers (USACE). 2000. Proceedings of the Turbine Fish Passage Survival Workshop. U.S. Army Corps of Engineers, Portland District, Portland, Oregon.

U.S. Army Corps of Engineers (USACE). 2004. Turbine Survival Program (TSP) Phase I Report, 19972002. U.S. Army Corps of Engineers, Portland District, Portland, Oregon.

Von Raben, K. 1957. "Regarding the problem of mutilations of fishes by hydraulic turbines." Originally published in Die Wasserwirtschaft (100):4:97. Fisheries Research Board of Canada Translation Series, No. 448, 1964.

Wittinger, R.J., and D. Ramirez. 2000. Bonneville Dam First Powerhouse, Unit 5 \& 6 Biological Test, November 1999-January 2000, Turbine Operating Conditions. Report to U.S. Army Corps of Engineers, Portland District, Portland, Oregon. 